\title{
REVIEW
}

\section{Inflammatory events in endometrial adenocarcinoma}

\author{
Alison E Wallace, Douglas A Gibson, Philippa T K Saunders and Henry N Jabbour \\ MRC Human Reproductive Sciences Unit, The Queen's Medical Research Institute, Centre for Reproductive Biology, 47 Little France Crescent, \\ Edinburgh EH16 4TJ, UK \\ (Correspondence should be addressed to H N Jabbour; Email: h.jabbour@hrsu.mrc.ac.uk)
}

\begin{abstract}
Endometrial adenocarcinoma is the most common gynaecological malignancy in western countries. Many of the established risk factors for developing endometrial cancer are associated with excess exposure to oestrogen unopposed by progesterone. These include nulliparity, late onset of the menopause, post-menopausal hormone replacement therapy and obesity. However, a number of risk factors also promote inflammation, another feature proposed to influence cancer development. The human cycling endometrium undergoes regular and cyclical episodes of inflammation. Moreover,

hormonal and genetic changes that occur early in the development of endometrial adenocarcinoma can exacerbate the local inflammatory environment. Via alterations in the expression of local mediators and immune cell function, these may contribute to the development of endometrial cancer. This review discusses the contribution of inflammation to the initiation and progression of endometrial adenocarcinoma. Manipulation of inflammatory pathways may therefore represent a therapeutic target in endometrial adenocarcinoma. Journal of Endocrinology (2010) 206, 141-157
\end{abstract}

\section{Introduction}

Endometrial adenocarcinoma, the neoplastic growth of endometrial epithelial cells, is the most common gynaecological malignancy in western, developed, countries (Doll et al. 2008). Post-menopausal women are mainly affected, with $\sim 86 \%$ of patients being over 50 years of age (Akhmedkhanov et al. 2001). The risk factors associated with endometrial adenocarcinoma include nulliparity (Albrektsen et al. 1995), late menopause onset (Kalandidi et al. 1996) and use of oestrogen-only hormone replacement therapy (HRT) (Grady et al. 1995, Beral et al. 2005, Karageorgi et al. 2010). Notably, a high body mass index increases the risk of developing endometrial cancer, and these patients have a poorer prognosis (Bergstrom et al. 2001, Gates et al. 2006, Rieck \& Fiander 2006, Reeves et al. 2007). A shared feature of these risk factors is an increased or prolonged exposure to oestrogens. This has led to the 'unopposed oestrogen hypothesis' to explain the development of endometrial adenocarcinoma. This proposes that an exposure to high oestrogen and low progesterone levels increases proliferation of endometrial cells, and therefore the risk of cancer development (Akhmedkhanov et al. 2001). However, a number of risk factors associated with the development of endometrial adenocarcinoma also promote another process implicated in the development of cancers - namely inflammation.

The concept that cancer and inflammation are linked was suggested as far back as the 19th century by Virchow.
After observing leukocyte influxes in cancers of tissues that had experienced chronic inflammatory conditions, he suggested that the leukocytes may be the cause of tumour growth (reviewed in Balkwill \& Mantovani (2001)). Inflammatory pathways have now been proposed to influence cancer development by two mechanisms, termed the intrinsic and extrinsic pathways (Colotta et al. 2009, Mantovani et al. 2009). In the former, after the initiation of cancer by genetic mutations, the expression of inflammatory agents is increased, leading to the promotion of tumour growth. In the extrinsic pathway, current inflammatory conditions lead to the initiation of cancer.

Epidemiological data have strengthened the extrinsic inflammatory hypothesis of cancer initiation, as inflammatory diseases have been shown to predispose sufferers to certain types of cancer. For example, inflammatory bowel disease is associated with an increased risk of colon cancer (Flossmann \& Rothwell 2007), prostatitis is associated with an increased risk of prostate cancer (Sandhu 2008) and infection with certain microbes can lead to increased risk of gastric cancer (Suzuki et al. 2009). Additionally, long-term intake of non-steroidal anti-inflammatory drugs (NSAIDs) in 'at risk' patients significantly reduces cancer incidence (Dannenberg \& Subbaramaiah 2003, Flossmann \& Rothwell 2007). The alternative intrinsic pathway hypothesis states that after cancer development, production of inflammatory mediators by cells is an ensuing feature that promotes tumour progression. The resulting inflammatory milieu comprises 
inflammatory mediators such as cytokines and prostaglandins, leukocytes, and extensive tissue remodelling including angiogenesis. This hypothesis is strengthened by studies inhibiting inflammatory conditions in tumours. In numerous in vivo models of cancer, prevention of cytokine signalling leads to a decrease in tumour growth or even tumour regression (Sparmann \& Bar-Sagi 2004, Loberg et al. 2007, Singh et al. 2009b). Furthermore, trials of antagonists of the pro-inflammatory cytokine tumour necrosis factor (TNF) in renal cancer patients have produced promising prognostic results at 12 months (Harrison et al. 2007). These studies support the hypothesis that inflammatory pathways occurring in tumours can promote cancer growth.

In this review, the contribution of inflammation to the initiation and progression of endometrial adenocarcinoma will be discussed. The concept that the normal cycling endometrium can be considered as a site of regular, repeated, inflammation will be considered, as will aspects of this process that may contribute to cancer development. Additionally, hormonal and genetic changes which occur early in the development of endometrial adenocarcinoma and lead to an upregulation of inflammatory mediators will be outlined.

\section{Clinical characteristics of endometrial adenocarcinoma}

Endometrial tumours are histologically classified into well-, moderately or poorly differentiated cancers, based on tissue architecture and the amount of solid tumour present (Ellenson \& Wu 2004). In 1983, it was proposed that endometrial adenocarcinoma can be broadly divided into two types (Bokhman 1983). Type I endometrial adenocarcinoma is associated with patients displaying increased oestrogen levels and hyperlipidaemia, and is often related to obesity. These tumours are the most common, occurring in $\sim 85 \%$ of patients, and they generally display low invasion with a good prognosis. These are usually classified as well- or moderately differentiated tumours; however, they can progress to become invasive and poorly differentiated. Type II endometrial adenocarcinoma is independent of oestrogen stimulation, and these are more aggressive, poorly differentiated tumours with a morphology consisting of cells growing in papillary patterns (Hendrickson et al. 1982). This dualistic model has been strengthened by more recent studies demonstrating that the two types of endometrial adenocarcinoma can be divided not only by morphology but also by genetic mutations (Tashiro et al. 1997, Lax et al. 2000, Catasus et al. 2009). There are overlapping features between the two types; however, due to its prevalence, most data discussed herein focus on type 1 endometrial adenocarcinoma.

\section{Inflammation in the normal menstrual cycle}

The uterus is a uniquely dynamic organ, and the endometrial lining is a highly specialised tissue consisting of a 'functional' layer closest to the uterine lumen supported by a basal layer adjacent to the myometrium. In pre-menopausal women, the endometrium undergoes regular cycles of proliferation, angiogenesis and differentiation in response to cyclical changes in sex steroid hormones (oestrogen and progesterone) secreted by the ovary. If implantation of an embryo does not occur during the progesterone-dominated secretory phase, the functional layer is shed as a consequence of the demise of the corpus luteum. This results in a decline in progesterone and menses occur (Jabbour et al. 2006). The human menstrual cycle was first explicitly likened to an inflammatory wound healing process in 1986 by Finn, who described the similarities of the two processes. These include increased blood flow and vessel permeability, the differentiation (decidualisation) of stromal tissue, which resembles the granulation tissue of wound healing, and the infiltration of immune cells (Finn 1986). Subsequent evidence has strengthened this analogy by examining in more detail the tissue remodelling, cytokine expression and leukocyte influxes that occur in the human endometrium (Salamonsen 2003, Jabbour et al. 2006). In the process of wound healing, an infiltration of leukocytes in response to cytokine production occurs before the re-growth of tissue mediated by growth factors such as epidermal growth factor (EGF) and plateletderived growth factor. Angiogenesis is mediated by local mediators including vascular endothelial growth factor (VEGF) and fibroblast growth factor (FGF; Barrientos et al. 2008). In the normal menstrual cycle, these events are mirrored by the influx of leukocytes at the time of tissue breakdown at menstruation, and the re-growth of the endometrium during the proliferative phase under the control of the same growth factors and angiogenic mediators (Critchley et al. 2001a).

At menstruation, degradation of the extracellular matrix occurs, and the upper layer of the endometrium is shed, drawing comparisons to tissue injury. The most notable inflammatory aspect of menstruation is the large influx of immune cells that comprise uterine natural killer (NK) cells, macrophages, neutrophils and eosinophils (Critchley et al. 1999). Immune cells are crucial in the process of menstruation, as demonstrated by the irregular endometrial breakdown and repair in a mouse model deficient in neutrophils (Kaitu'u-Lino et al. 2007). Inflammatory chemokines such as macrophage inflammatory protein- $1 \alpha$ are released from the denuded epithelium during menstruation, and this may promote infiltration of macrophages, which then contribute to the tissue destruction and promotion of apoptosis seen at menstruation (Akiyama et al. 1999). In wound healing or inflammatory situations, the similar infiltration of leukocytes such as macrophages and neutrophils acts to breakdown the extracellular matrix by phagocytosis of cell and matrix material (Uutela et al. 2004).

The endometrium then enters the proliferative phase of the menstrual cycle, which starts on days $2-3$ of the menstrual cycle, and is a period of tissue remodelling. This phase entails the growth of the endometrium in response to rising 
concentrations of oestrogen and a number of locally produced angiogenic and growth factors. These include chemokines such as interleukin 8 (IL8), which is expressed in the epithelial cells (Arici et al. 1998) and perivascular cells (Critchley et al. 1994). Macrophage chemoattractant protein-1 is also produced in the stroma and perivascular cells (Jones et al. 1997). CCL5 (also known as RANTES) is chemotactic for monocytes and activated $\mathrm{T}$ cells, and is expressed in the proliferative endometrial stroma (Hornung et al. 1997). The upregulation of these cytokines causes the infiltration of macrophages and neutrophils seen at this stage of the cycle (Kelly et al. 1994). Macrophages are able to secrete growth factors such as EGF (Schultz et al. 1991) and heparin-binding EGF (Edwards et al. 2009) and so may contribute to endometrial re-growth by this mechanism. Macrophages also produce a range of angiogenic factors (Lin et al. 2006) including VEGF in the endometrium (Gargett et al. 2001). Neutrophils at this stage of the cycle are observed adjacent to the vasculature, and produce VEGF, and therefore may be involved in vascular remodelling (Gargett et al. 2001). These factors are also all produced to orchestrate wound healing in inflammatory situations (Barrientos et al. 2008).

The secretory phase of the menstrual cycle follows the proliferative phase, and in the mid-secretory phase, the endometrium is receptive to embryo implantation. A number of cytokines are up-regulated during this phase, including IL11 (Dimitriadis et al. 2000), leukemia inhibitory factor (Cullinan et al. 1996) and IL6 (Tabibzadeh et al. 1995). These factors are thought to aid adhesion and invasion of the blastocyst into the endometrium (Marwood et al. 2009). Increased permeability of the endometrial vasculature is reported in many animal species to facilitate implantation (Rowe et al. 2003, Pakrasi \& Tiwari 2007).

The inflammatory nature of the normal menstrual cycle is therefore reflected by chemokine expression by endometrial cells and leukocyte infiltration into the endometrium. As described, chronic inflammatory conditions in tissues have been demonstrated to predispose to cancer (Flossmann \& Rothwell 2007, Sandhu 2008, Suzuki et al. 2009). The local regulation of the molecular pathways that contribute to exacerbated angiogenesis and immune cell function in endometrial cancer remains largely unidentified. Understanding how inflammation and its resolution are tightly controlled in normal endometrial events such as menstruation may help shed some insight about the molecular events that lead to their exacerbated activities in cancer.

\section{Hormones and inflammation in endometrial adenocarcinoma}

\section{Oestrogen and progesterone signalling}

In addition to circulating steroid hormones, evidence for local biosynthesis of oestrogens associated with the expression of enzymes such as CYP19A1 (aromatase) has been documented in endometrial carcinomas (Bulun et al. 1994). Oestradiol $\left(\mathrm{OE}_{2}\right)$ has been measured in tumour tissues and correlated with the rate of tumour invasion in both pre- and postmenopausal women (Berstein et al. 2003). Steroid hormone action is classically mediated by receptors that act as ligandactivated transcription factors. Oestrogen and progesterone can each bind two main receptor isoforms oestrogen receptor (ESR1) and ESR2, and progesterone receptor A (PGRA) and PGRB, respectively. Expression of ESRs in normal premenopausal endometrium has been well documented with the expression of ESR1 being intense in both glands and stroma during the proliferative, oestrogen-dominant phase but reduced in the secretory phase following the post-ovulatory rise in progesterone (Critchley et al. 2001b). Oestrogen promotes endometrial proliferation (Ferenczy et al. 1979) and vascularisation (Hastings et al. 2003). Studies using mice with targeted deletion of the ESR1 gene have reported that this subtype plays an essential role in uterine cell proliferation and expression of the progesterone receptor gene (reviewed in Couse \& Korach (1999)). Additionally, studies in cell lines have suggested that ESR2 acts as an inhibitory modulator of ESR1-stimulated gene transcription (Hall \& McDonnell 1999), and differential activation of reporter genes by ESR 1 and ESR 2 in response to selective ESR modulators (SERMs) has been described (Paech et al. 1997). The net action of oestrogen or SERMs on endometrial gene expression and cell proliferation will therefore be influenced both by the pattern of expression of ESR subtypes and the relative levels of expression of ESR1 and ESR2 in cells where they are co-expressed. Notably gene array analysis has identified specific differences in the response of primary endometrial cells to $\mathrm{OE}_{2}$ and tamoxifen (a SERM frequently used in the treatment of breast cancer) with the latter most closely resembling gene expression patterns in malignant endometrium (Pole et al. 2005). It has been reported that total concentrations of ESR2 mRNAs decrease in the postmenopausal endometrium (Jazaeri et al. 2001) which might make post-menopausal endometrium more sensitive to oestrogens through unopposed ESR1 action. An imbalance in ESR isoform expression could therefore have a significant effect in oestrogen-driven hyperplasia and tumourigenesis especially if this occurred in parallel with anovulatory cycles such as during the menopausal transition (Hale et al. 2002).

In premenopausal women, activation of PGR during the secretory phase of the cycle results in reduced endometrial proliferation. If progesterone biosynthesis is inadequate, the endometrium can become hyperplastic, and this increases the risk of developing endometrial adenocarcinoma. Expression of PGR is under the control of both oestrogen and progesterone, which induce PGR synthesis and downregulate PGR expression respectively (Horwitz \& McGuire 1978, Alexander et al. 1989). The two PGR isoforms have distinct functions. PGRA acts as a transcriptional repressor, and has a major role in the endometrium by inhibiting oestrogen-induced proliferation. PGRB has an 
activating role in the endometrium by acting as an endometrial oestrogen agonist (Doll et al. 2008).

Expression of ESRs and PGR in endometrial cancer is grade dependent, and decreased expression of ESR 1 and PGR in poorly differentiated cancers has been documented, even though the expression of ESR2 is maintained (Hanekamp et al. 2003, Collins et al. 2009). Notably, expression of PGR is associated with better disease-free survival (Ito et al. 2007). Expression of PGR is downregulated in more aggressive tumours, such as malignant mixed Mullerian tumours (5\% of all endometrial cancers), that do not respond to endocrine treatment. The ratio of PGR isoform expression is important as alterations may precede changes leading to endometrial carcinoma. For example, an increase in PGRB due to a polymorphism in PGR promoter alters PGR isoform ratio, and is associated with an increased risk of developing endometrial cancer (Doll et al. 2008). Loss of PGR expression is associated with latestage disease that is unresponsive to progesterone treatment. Progesterone has been shown in the PGR-expressing Ishikawa cell line to downregulate genes involved in invasion and metastasis such as CD44, and CSPG/Versican, which are upregulated in endometrial tumours that lack PGR. Therefore, progesterone exposure and receptor expression can affect tumour cell invasion and metastasis (Hanekamp et al. 2003).

\section{Oestrogen, progesterone and inflammation}

Homeostasis in reproductive tissues requires integration of the hormonal signals described above and inflammatory signals. Pro-inflammatory signals can switch repressed steroid hormone receptors into transcriptional activators (Brosens et al. 2006). Oestrogens can influence inflammatory processes, although their role is recognised as complex and cell context dependent (reviewed in Straub (2007)). For example, oestrogens are associated with decreased severity of inflammatory disease symptoms during pregnancy, but women also show an increased incidence of autoimmune disease, indicating that pro-inflammatory functions of female sex hormones also exist (Nilsson 2007). In the normal endometrium, oestrogen upregulates the expression of a number of inflammatory cytokines including IL6 (Jacobs et al. 1992). Production of this cytokine, in both the KLE and RL95 endometrial adenocarcinoma cell lines after oestrogen stimulation, has also been demonstrated (He et al. 2009). Other inflammatory mediators upregulated by oestrogen include IL1, TNF- $\alpha$, and matrix metalloproteinases (MMPs) (Modugno et al. 2005, He et al. 2009), and IL1B can enhance the actions of oestrogen (King et al. 2009). Oestrogen can also activate nuclear factor kappa-light-chain-enhancer of activated B cells (NFKB) signalling in endometrial cancer, a key transcription factor regulating the expression of many inflammatory mediators (Seo et al. 2004). The potential interactions of oestrogen and inflammatory signals are summarised in Fig. 1.

Progesterone can negatively influence production of a number of inflammatory mediators. A number of in vitro studies demonstrate that progesterone can inhibit cytokine release from murine and human uterine cells (Ito et al. 1994, Kelly et al. 1994, 1997). Many of these cytokines are under the control of NFKB. For example, in the Hec50co poorly differentiated endometrial adenocarcinoma cell line, progesterone inhibits $\mathrm{NF} \kappa \mathrm{B}$ activation by inducing accessory proteins which form a complex, inhibiting NFKB activity

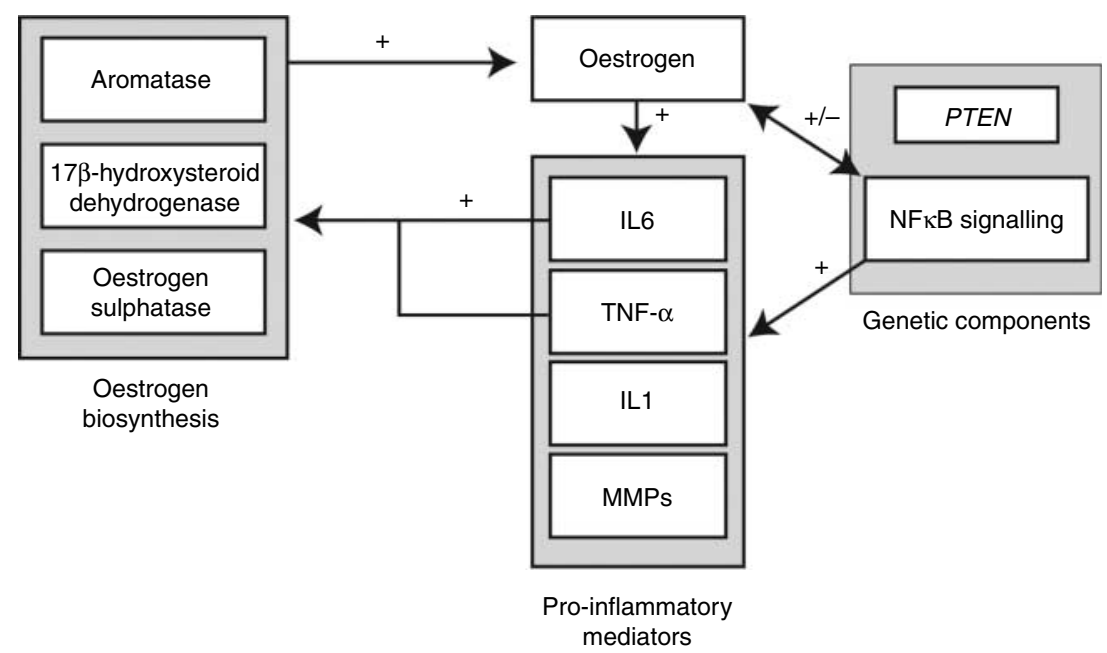

Figure 1 Interactions between oestrogen, inflammatory mediators and genetic aspects of endometrial adenocarcinoma. Oestrogen stimulates the production of pro-inflammatory mediators such as IL6 and TNF- $\alpha$, which in turn can stimulate oestrogen biosynthesis. Both oestrogen and PTEN mutation can also stimulate $N F \kappa B$ activity, further promoting inflammation. Thus, oestrogen-mediated stimulation of pro-inflammatory factors and activation of NFKB signalling can promote a pro-oestrogen, pro-inflammatory state. 
(Davies et al. 2004). In vivo data have demonstrated that mice lacking PGR have increased inflammatory responses in the uterus, with an increased infiltration of leukocytes and extensive tissue remodelling (Lydon et al. 1995). Progesterone also stimulates the production of prostaglandin dehydrogenase and inhibits cytokine-induced transcription of cyclooxygenase 2 (COX2), thereby reducing prostaglandin production and consequent inflammation (Ishihara et al. 1995, van der Burg \& van der Saag 1996) Therefore, as endometrial adenocarcinoma is characterised by increased oestrogen to progesterone signalling, an increase in inflammatory mediators may occur, thus promoting tumour growth.

The pro-inflammatory milieu in endometrial cancer can also directly increase oestrogen production (Modugno et al. 2005). IL6 can stimulate oestrogen synthesis and can act synergistically with TNF- $\alpha$ to increase aromatase, $17 \beta$-hydroxysteroid dehydrogenase and oestrone sulfatase activity, thus increasing local oestrogen biosynthesis (Modugno et al. 2005, Salama et al. 2009). TNF- $\alpha$ increases local oestrogen biosynthesis in human endometrial glandular epithelial cells and directs oestrogen metabolism to produce more hormonally active and carcinogenic metabolites. Thus, TNF- $\alpha$ can act as a potential auto- and paracrine regulator of endometrial steroidogenesis (Salama et al. 2009).

Oestrogen metabolites can influence uterine activity in different ways. 16 $\alpha$-Hydroxylation and 4-hydroxylation metabolites are potent oestrogens in the uterus, whereas 2-hydroxylation products such as 2-hydroxyoestradiol and 2-methoxyoestradiol do not stimulate the uterus (Martucci \& Fishman 1977). 2-Methoxyoestradiol may even be protective in the uterus as it seems to inhibit tumour growth, induce apoptosis as well as inhibiting inflammatory cytokines IL6 and TNF- $\alpha$ production (Purohit et al. 1999, Purohit \& Reed 2002). Oestrogen metabolism could therefore affect endometrial cancer risk depending on which pathways are favoured. Smoking is associated with a shift to 2-hydroxylation pathway (Michnovicz et al. 1986) which produces metabolites that do not stimulate uterine growth and may inhibit tumour growth. This may account for some of the protective effect that is associated with smoking and endometrial cancer.

Therefore, endometrial cancer is characterised by alterations in steroid receptor isoform expression leading to an increased ratio of oestrogen to progesterone signalling. This can promote endometrial proliferation and increase inflammatory mediators, leading to the promotion of tumour growth.

\begin{abstract}
Androgens
Polycystic ovarian syndrome is a common condition associated with elevated circulating androgens. A recent systematic review (Chittenden et al. 2009) reported that women with PCOS are more likely to develop endometrial and ovarian cancers. Androgen receptors (ARs) are expressed in the endometrium throughout the menstrual cycle, with
\end{abstract}

highest concentrations in stromal fibroblasts during the proliferative phase and upregulation in the expression in epithelial cells coincident with progesterone withdrawal (Critchley \& Saunders 2009). Overexpression of AR and steroid co-activators in the endometrium of women with polycystic ovarian syndrome has been described (Giudice 2006). It has been suggested that CAG repeat polymorphisms in the first exon of the AR gene could be associated with increased endometrial cancer risk due to reduced capacity of AR to recruit coregulators and transcriptional components (McGrath et al. 2006), although this has been disputed (Ju \& Kim 2007, Yang et al. 2009). Expression of AR and $5 \alpha$-reductase type 1 and type 2 enzymes has been detected in 88 and $80 \%$ of endometrial adenocarcinomas respectively (Ito et al. 2002). As overexpression of aromatase has been reported to occur in $50 \%$ of endometrial adenocarcinomas, testosterone may act directly to modulate cell activity but also following conversion to dihydrotestosterone (DHT) or $\mathrm{OE}_{2}$ (Ito et al. 2002). In the Ishikawa endometrial adenocarcinoma cell line, expression of AR was induced by oestrogen or DHT, and down-regulated by the progestin medroxyprogesterone acetate (MPA) or the anti-androgen hydroxyflutamide (Lovely et al. 2000, Apparao et al. 2002). There is evidence to suggest that the regulation of insulin-like growth factor 1 (IGF1) by androgens may influence endometrial cell proliferation (Sahlin et al. 1994, Gori et al. 1999). Expression of IGF1 is also up-regulated by oestrogen in Ishikawa cells, and treatment with recombinant IGF1 stimulated cell proliferation in a dose-dependent fashion (Kashima et al. 2009). Androgens may therefore have both a direct, AR-mediated impact and an indirect, ESR-mediated impact on endometrial proliferation and inflammation.

\section{Glucocorticoids}

Glucocorticoids are well-known anti-inflammatory agents, and have been shown to limit the production of cytokines and prostaglandin synthesis. The glucocorticoid receptor (GR), as well as enzymes capable of biosynthesis of cortisol, is expressed in the human endometrium (Bamberger $e t$ al. 2001, McDonald et al. 2006). Little is known about the role of glucocorticoids in endometrial cancer; however, GR expression has been shown to be altered with HRT (Vani et al. 2008), which may suggest that GR expression could be affected by altered steroid signalling in endometrial cancer.

\section{Genetic and cellular changes contributing to inflammation in endometrial adenocarcinoma}

A number of genetic mutations are associated with endometrial adenocarcinoma. These often occur in genes encoding proteins which contribute to an inflammatory microenvironment, impacting on cytokine expression, leukocyte infiltration and tissue remodelling. 


\section{PTEN}

The most common genetic mutation in endometrial adenocarcinoma is in the tumour suppressor gene PTEN, leading to its inactivation (Tashiro et al. 1997). PTEN encodes the phosphatase and tensin homologue protein, which is a lipid phosphatase that downregulates phosphatidylinositol$(3,4,5)$-trisphosphate $\left(\mathrm{PIP}_{3}\right)$ by converting it into $\mathrm{PIP}_{2} . \mathrm{PIP}_{3}$ activates AKT signalling; therefore, the common inactivation of PTEN found in endometrial adenocarcinoma can upregulate AKT signalling and subsequently impact on the signalling pathways regulated by this protein. These include control of cellular proliferation, adhesion and migration (Maehama \& Dixon 1998). The impact of this mutation on endometrial adenocarcinoma development was recently demonstrated by the conditional deletion of Pten in the endometrium of a mouse model. This rapidly induced endometrial cancer formation (Daikoku et al. 2008). PTEN and AKT have also been linked to the control of NFKB. In endometrial adenocarcinoma cell lines containing mutated PTEN, increased levels of AKT phosphorylation resulted in the presence of activated $\mathrm{NF} \kappa \mathrm{B}$ in the nucleus (St-Germain et al. 2004).

\section{$N F \kappa B$}

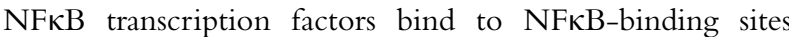
on DNA to initiate the transcription of numerous cytokines and inflammatory mediators. NFKB activation can occur downstream of growth factor receptors and G-protein-coupled receptors after the activation of the phosphatidylinositol 3-kinase and AKT signalling pathway (Ye 2001). This method of activation in cancer is commonly due to the genetic alterations in tumour cells (Courtois \& Gilmore 2006). It is also activated by inflammatory cytokines such as IL1, and Toll-like receptor signalling (Pomerantz \& Baltimore 2002). The final step in the NFKB signalling pathway occurs when the inhibitory $\mathrm{I} \kappa \mathrm{B}$ complex is phosphorylated by the I $\kappa \mathrm{B}$ kinases (IKKs). The dissociation of $\mathrm{I} \kappa \mathrm{B}$ from $\mathrm{NF} \kappa \mathrm{B}$ allows the translocation of $\mathrm{NF} \kappa \mathrm{B}$ to the nucleus and initiation of gene transcription (Ye 2001). In cancer, $\mathrm{NF} \kappa \mathrm{B}$ activation by these pathways leads to the development of numerous characteristics of inflammation. The involvement of NFKB in tumour development has been demonstrated in tissues displaying chronic inflammation. For example, a conditional knock-out of IKK, and therefore NFKB signalling, was introduced into a mouse model of gastric cancer which develops from chronic colitis. In these mice, tumour incidence was decreased by $75 \%$, and this was associated with an increase in epithelial cell apoptosis and a decrease in inflammatory cytokine production by leukocytes. This provided a direct proof of the role of inflammation in initiation of this cancer type (Greten et al. 2004). Furthermore, NFKB activation contributes to tumour progression in tissues, in which cancer initiation is not linked to chronic inflammation. In ovarian cancer, for example, increased NFKB signalling has been identified which promotes tumour progression through the production of various angiogenic and mitogenic cytokines such as IL8 and CXCL1 (Chen et al. 2008).

In endometrial adenocarcinoma, increased localisation of $\mathrm{NF} \kappa \mathrm{B}$ to the nucleus has been detected, therefore implying an upregulation of $\mathrm{NF \kappa B}$ signalling and hence inflammation (Pallares et al. 2004). In addition to the connection to PTEN inactivation already described, NFKB is influenced by the hormonal environment in endometrial adenocarcinoma. This further links the unopposed oestrogen hypothesis and inflammation. For example, NFKB can be activated by oestrogen in HEC-1A endometrial adenocarcinoma cells to increase the expression of angiogenic factors including VEGF and FGF, and the cytokines IL1, IL8 and TNF- $\alpha$ (Seo et al. 2004). The protease MMP9 is also released by three endometrial adenocarcinoma cell lines, HEC-1A, KLE and AN3CA, following oestrogen-induced NFKB signalling (Oh et al. 2009). Increased MMP production is a feature of many tumours leading to increased cancer cell invasion and metastasis. Additionally, in a poorly differentiated endometrial adenocarcinoma cell line, progesterone inhibits NFKB activation by inducing accessory proteins which form a complex inhibiting NFKB activity (Davies et al. 2004). This further indicates that the increased oestrogen environment in endometrial adenocarcinoma favours inflammation via the transcription factor NFKB.

\section{Kras}

Additional genetic mutations found in endometrial adenocarcinoma are capable of promoting an inflammatory environment. A mutation in the oncogene Kras is detected in $9-33 \%$ of endometrial adenocarcinomas (Enomoto et al. 1990, Lax et al. 2000). Kras mutations can cause constitutive activation of the extracellular signal-regulated kinase $1 / 2$ (ERK1/2) signalling pathway in the absence of stimuli. This is a mitogen-activated protein kinase pathway, and therefore leads to transcription of numerous genes promoting tumour progression (Mizumoto et al. 2007). This mutation is also more commonly found in poorly differentiated cancers (Kohler et al. 1992), indicating that it may be associated with a poor prognosis. The phenotypic effects of Kras mutations in endometrial adenocarcinoma are yet to be determined, but are likely to involve the activation of multiple pathways regulated by ERK signalling which can promote growth, migration and angiogenesis (Lax et al. 2000). In other cancer types, mutations in Ras have been linked to inflammatory conditions. For example, constitutive Ras signalling in breast, lung and cervical cancer cell lines promotes the production of inflammatory chemokines including IL8 (Sparmann \& Bar-Sagi 2004).

Thus, genetic mutations identified in endometrial adenocarcinoma can contribute to an inflammatory microenvironment, and in some cases tumour initiation. 


\section{Local mediators of inflammation in endometrial adenocarcinoma}

The hallmarks of an inflammatory environment include local secretion of cytokines and other inflammatory mediators, and the presence of leukocytes. This review has thus far discussed how these features are promoted in endometrial adenocarcinoma by hormonal and genetic alterations to signalling. The contribution of local mediators and leukocytes to the inflammatory environment in endometrial adenocarcinoma will now be considered (summarised in Table 1).

\section{Cytokines and chemokines}

Cytokines are small peptides released by cells which can act as growth signals and chemotactic agents. In endometrial adenocarcinoma, cytokines can promote tumour growth by mediating cell invasion and angiogenesis. For example, the pro-inflammatory cytokine TNF- $\alpha$ activates signalling pathways, which are crucial for endometrial adenocarcinoma cell invasion (Choi et al. 2009). TNF- $\alpha$ also promoted angiogenesis in a mouse model by the activation of $\mathrm{NF} \kappa \mathrm{B}$ (Seo et al. 2004). IL6 is a further pro-inflammatory cytokine up-regulated in endometrial adenocarcinoma (Slater et al. 2006), which is associated with a poor prognosis (Bellone et al. 2005).

Chemokines are a subfamily of cytokines, so named for their chemoattractant properties. The chemokine family is divided into four groups based on the position of two cysteine molecules (C) and any other amino acid (X) in the amino terminal of the protein. The groups are known as $\mathrm{C}, \mathrm{C}-\mathrm{C}$, C-X-C and C-X3-C (Murphy et al. 2000). A number of C-X-C chemokines are angiogenic (Strieter et al. 1995) and mitogenic (Wang et al. 2006a, Singh et al. 2009a). Their tumour-promoting properties have been demonstrated in mouse models of other cancer types such as melanoma, lung

Table 1 The expression of inflammatory mediators in endometrial adenocarcinoma

\section{Expression in endometrial adenocarcinoma}

\section{Inflammatory mediator \\ Cytokines$$
\text { CCL2 }
$$ \\ CXCL1 \\ CXCL5 \\ CXCL12}

IL1

IL6

IL8

IL11

TNF- $\alpha$

Leukocytes

Macrophages

\section{Neutrophils \\ B cells \\ T cells}

NK cells

Prostaglandins

$\mathrm{PGE}_{2}$

Increased EP

Increased EP

Increased EP

Increased EP

Increased EP

$\mathrm{PGF}_{2 \alpha}$

$\begin{array}{ll}\text { Increased } & \text { Unknown } \\ \text { Increased } & \text { Unknown } \\ \text { Increased } & \text { Unknown } \\ \text { Unknown } & \text { Increased cell proliferation } \\ \text { Unknown } & \text { Increased cell migration } \\ \text { Increased } & \text { Increased angiogenesis } \\ \text { Increased } & \text { Unknown } \\ \text { Increased } & \text { Unknown } \\ \text { Increased } & \text { Increased angiogenesis } \\ & \text { Increased metastasis } \\ \text { Increased } & \text { Unknown } \\ \text { Increased } & \text { Increased angiogenesis } \\ \text { Increased } & \text { Increased cell invasion } \\ & \\ \text { Increased } & \text { Unknown } \\ \text { Increased } & \text { Promotion of angiogenesis } \\ \text { Increased } & \text { Unknown } \\ \text { Increased } & \text { Promotion of angiogenesis } \\ \text { Increased } & \text { Unknown } \\ \text { Increased } & \text { Unknown } \\ \text { Increased } & \text { Unknown } \\ \text { Increased (CD8) } & \text { Unknown } \\ \text { Increased (CD8) } & \text { Unknown } \\ \text { Increased (CD4) } & \text { Promotion of angiogenesis } \\ \text { Decreased (grades 1 and 2 EC) } & \text { Unknown } \\ \text { Increased (gade } 3 \text { EC) } & \end{array}$

Increased cAMP expression Increased COX2 expression Increased cell proliferation Increased VEGF expression Increased FGF expression Increased cell proliferation Increased VEGF expression Increased FGF expression Increased cell migration
References

Wang et al. $(2006 a, b)$

Wallace et al. (2009)

Wong et al. (2007)

Zhao et al. (2006)

Tsukamoto et al. 2007

Seo et al. (2004)

Slater et al. (2006)

He et al. (2009)

Fujimoto et al. (2002)

Berry et al. (2001)

Sales et al. (2010)

Seo et al. (2004)

Choi et al. (2009)

Salvesen \& Akslen (1999)

Tanaka et al. (2002)

Ohno et al. (2004)

Soeda et al. (2008)

Wallace et al. (2009)

Hachisuga et al. (1997)

Hachisuga et al. (1997)

Kondratiev et al. (2004)

Ohno et al. (2005)

Giatromanolaki et al. (2008)

Hachisuga et al. (1997)

Jabbour et al. (2001)

Tamura et al. (2002)

Jabbour \& Boddy (2003)

Sales et al. (2004a,b)

Battersby et al. (2006)

Sales et al. (2004b)

Sales et al. (2005)

Sales et al. (2007)

Sales et al. $(2008 a, b)$ 
and prostate cancer (Haghnegahdar et al. 2000, Keane et al. 2004, Singh et al. 2009b). In endometrial adenocarcinoma, expression of the CXCR 4 receptor is elevated. This receptor is activated by the chemokine CXCL12 (also known as stromal cell-derived factor-1; Gelmini et al. 2009). In vitro studies have demonstrated that signalling of CXCL12 through this receptor increases proliferation, migration and invasiveness of various endometrial adenocarcinoma cell lines (Zhao et al. 2006, Tsukamoto et al. 2007). Elevated expression of CXCR 4 in endometrial adenocarcinoma was also examined in a nude mouse xenograft model, and found to lead to a significantly higher incidence of metastases (Gelmini et al. 2009). Notably, a recent study provides evidence for an autocrine loop between the CXCR4/SDF1 and ESR1/ ESR2 signalling pathways, which alters growth of breast cancer cells (Sauve et al. 2009), and it will be interesting to see if the same applies to endometrial cancers. Other members of the CXC chemokine family, CXCL1 and IL8 (also known as CXCL8), are elevated in endometrial adenocarcinoma (Berry et al. 2001, Wallace et al. 2009). IL8 expression was associated with increased metastatic potential (Berry et al. 2001) and increased angiogenesis in endometrial tumours, as measured by microvascular density counts (Fujimoto et al. 2002). CXCL5 expression is also elevated in endometrial adenocarcinoma (Wong et al. 2007), and may perform similar functions to IL8.

Other chemokines in addition to those of the CXC family are implicated in the progression of endometrial adenocarcinoma. The chemokine CCL2, also known as monocyte chemotactic protein-1, is up-regulated in endometrial adenocarcinoma cells (Wang et al. 2006b). CCL2 has been proposed to have direct angiogenic effects on microvascular endothelial cells and migratory effects on neoplastic epithelial cells (Conti \& Rollins 2004).

\section{Leukocytes}

In addition to direct effects on neoplastic endometrial cells and endothelial cells, cytokines may also promote the development of endometrial adenocarcinoma through the chemo-attraction of immune cells. Leukocytes are a hallmark of inflammation, as well as promoters of inflammation and Virchow's original observation that cancer and inflammation may be linked was based on the observation of leukocytes in tumours (Balkwill \& Mantovani 2001). The tumour microenvironment is commonly infiltrated by leukocytes of the innate immune system including macrophages, neutrophils, NK cells and dendritic cells. The cells of the adaptive immune system, $\mathrm{T}$ and $\mathrm{B}$ lymphocytes, are also found in tumours. Innate immune cells are attracted by the proinflammatory cytokines secreted by the tumour. After this initial infiltration, activation of antigen-presenting cells such as dendritic cells may result in the recruitment of adaptive immune cells to the tumour. Leukocytes have been shown to play contrasting roles in tumour promotion and destruction (de Visser et al. 2006). In endometrial cancer, the infiltration of macrophages (Salvesen \& Akslen 1999, Ohno et al. 2004), neutrophils (Wallace et al. 2009) and B and T lymphocytes (Yamazawa et al. 2001, Chang et al. 2005, Ohno et al. 2005, 2006, Miyatake et al. 2007, Giatromanolaki et al. 2008) were increased as compared with normal endometrial tissue. Recent data from our laboratory have compared the presence of neutrophils, macrophages, dendritic cells, T cells, B cells and NK cells in well-, moderately and poorly differentiated endometrial adenocarcinoma. The numbers of neutrophils, macrophages and dendritic cells were significantly increased, and NK cells were significantly decreased in endometrial adenocarcinoma compared with normal endometrial tissue (Fig. 2).

Macrophages have been recently identified as a crucial link between chronic inflammation and the development of cancer, with the evidence that the prevention of macrophage infiltration significantly reduced the incidence and severity of inflammation-induced colon cancer (Popivanova et al. 2009). Tumour-associated macrophages have primarily been associated with the promotion of angiogenesis, as evidence in other cancer types has shown that they can secrete a range of angiogenic factors including VEGF and angiopoietins (Bingle et al. 2006, Venneri et al. 2007). Their contribution to cancer was demonstrated in a mouse model of breast cancer lacking macrophage infiltration. In these mice, a greatly decreased tumour progression and metastasis rate were

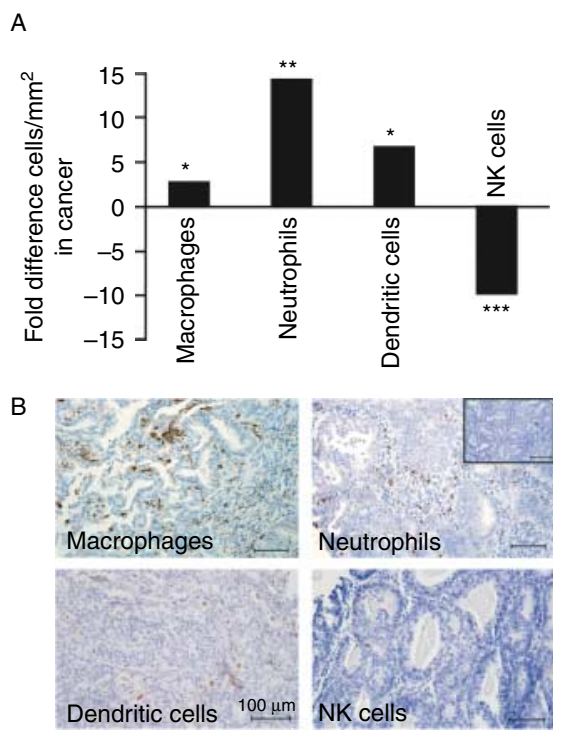

Figure 2 Immune cells in endometrial adenocarcinoma. (A) The number of immune cells $/ \mathrm{mm}^{2}$ in endometrial adenocarcinoma tissue relative to numbers in normal proliferative phase endometrium. The numbers of macrophages, neutrophils and dendritic cells were significantly increased in cancer. The number of NK cells was significantly decreased. Data are displayed as the fold difference between average cell numbers, $* P<0 \cdot 05, * * P<0 \cdot 01$, ${ }^{* * *} P<0 \cdot 001$ as compared to normal endometrium. (B) Representative images of neutrophils, macrophages and dendritic cells in endometrial adenocarcinoma. Negative control is inset; scale bars represent $100 \mu \mathrm{M}$. 
demonstrated, and the re-introduction of macrophages enabled tumour progression to rapidly catch up with control counterparts (Lin et al. 2001). Macrophage infiltration has been associated with a poor prognosis in endometrial cancer patients (Salvesen \& Akslen 1999, Yang et al. 2007). In endometrial adenocarcinoma, the promotion of angiogenesis by macrophages has also been implicated, as macrophages are associated with increased microvascular density (Soeda $e t$ al. 2008). Furthermore, the promotion of angiogenesis is suggested by a study correlating expression of platelet-derived endothelial cell growth factor (thymidine phosphorylase) by macrophages with increased microvascular density in endometrial adenocarcinoma (Tanaka et al. 2002).

Neutrophils are proposed to contribute to tumour progression in a similar mechanism to macrophages, by tissue remodelling through the production of angiogenic factors and proteases. In the normal endometrium, neutrophils are found close to or associated with endothelial microvessels, and express VEGF during or coincident with periods of angiogenesis (Gargett et al. 2001). Neutrophils produce angiogenic factors including VEGF and FGF (Gargett et al. 2001, Scapini et al. 2004, Ai et al. 2007), and promote invasion and metastasis through the production of proteases including MMP9 (Ardi et al. 2007). In a nude mouse model of breast cancer, an increased infiltration of neutrophils increased invasiveness of the tumour, likely due to protease production (Yao et al. 2007). In addition, the depletion of neutrophils in mouse models of fibrosarcoma and colon cancer significantly decreased metastasis in these animals (Tazawa et al. 2003, Yamamoto et al. 2008). The increase in neutrophil infiltration in endometrial adenocarcinoma induced by elevated chemokine expression has been described (Wallace et al. 2009); however, the exact role that they are playing in endometrial adenocarcinoma is as yet unclear.

Most evidence points towards a cytotoxic role for $\mathrm{T}$ cells in cancer. Both CD4+ and CD8 $+\mathrm{T}$ cells can recognise tumour antigen and eradicate tumours from mouse models through the production of cytokines (Nishimura et al. 1999). To support this, a low infiltration of $\mathrm{CD} 8+\mathrm{T}$ cells into endometrial cancer has previously been associated with a poor prognosis (Kondratiev et al. 2004, Ohno et al. 2005). However, the plasticity and complexity of immune cell responses to tumours is demonstrated by $\mathrm{CD} 4+\mathrm{T}$ cells. A subset of these are known as regulatory $\mathrm{T}$ cells, as indicated by the specific expression of the cell surface antigen forkhead box p3 (FOXP3) which drives the development of this cell type. These cells have a distinct phenotype which can suppress $\mathrm{T}$ cell population expansion and cytotoxicity, and are associated with increased microvascular density and angiogenic factor production including VEGF in endometrial adenocarcinoma (Giatromanolaki et al. 2008). Additionally, the production of cytokines by $T$ cells may also recruit other cells of the innate immune system, such as macrophages, and therefore indirectly lead to tumour promotion (Badoual et al. 2006).

Dendritic cells are the main antigen-presenting cells of the immune system, which infiltrate tissues as immature cells.
Upon the uptake of antigen and in response to inflammatory stimuli, they differentiate into mature dendritic cells capable of activating lymphocytes (Schutyser et al. 2003). In cancer, increased numbers of immature dendritic cells in the tumour have been demonstrated to promote immune tolerance to the tumour. Immature dendritic cells taken from the tumour of a mouse model of colon cancer induced lower levels of $\mathrm{T}$ cell clonal expansion than mature dendritic cells (Bonnotte et al. 2004). It is possible that factors derived by the tumour promote dendritic cell immaturity or inhibit differentiation. For example, VEGF (Gabrilovich et al. 1998) and the overexpression of CCL2O by colon cancer cells have been demonstrated to preferentially recruit immature dendritic cells in vitro (Wang et al. 2008). Similarly to other leukocytes discussed here, dendritic cells can also produce a host of angiogenic factors, including VEGF (Fainaru et al. 2008). However, their role in endometrial adenocarcinoma has not yet been examined.

NK cells are cytotoxic to tumour cells which do not express MHC class I (Zamai et al. 2007). Upon recognition, NK cells secrete a variety of lytic factors from specialised granules, able to lyse and promote apoptosis of targeted tumour cells. Therefore, presence of NK cells in a tumour is likely to decrease tumour growth (Zamai et al. 2007). In a mouse model of sarcoma, complete depletion of NK cells led to an increased rate of tumour initiation (Smyth et al. 2001). Additionally, NK cells can contribute to tumour destruction by the production of anti-angiogenic factors, including interferon- $\gamma$ (Hayakawa et al. 2002). Therefore, the decrease in NK cell infiltration into endometrial adenocarcinoma observed in our laboratory (Fig. 2) indicates a reduction in immune cells with tumour-destructive properties.

\section{Anti-tumourigenic roles of leukocytes}

Although much evidence points to a pro-tumourigenic role for inflammation, there is still a controversy surrounding this subject in cancer. This is illustrated well by the actions of chemokines and leukocytes in different cancer types. Increased chemokine expression may drive angiogenesis or cell proliferation, but also an infiltration of immune cells cytotoxic to cancer cells. The cytotoxic nature of lymphocytes has already been discussed, and both neutrophils and macrophages have been shown in mouse models of different cancer types to reduce tumour growth (Lee et al. 2000, Lavergne et al. 2004). Additionally, the possibility of activating dendritic cells as an anti-tumour therapy is currently being investigated, as some evidence shows that mature dendritic cells can activate cytotoxic lymphocytes (Palucka et al. 2010). It may be that the balance of chemokines and leukocytes determines the pro- or anti-tumourigenic outcome. This has been previously suggested regarding macrophage infiltration, where infiltration in very large numbers may lead to tumour destruction (Mantovani et al. 2009). In endometrial cancer, no studies as yet show an inhibitory effect of leukocyte 
infiltration on tumour growth; however, in some gynaecological cancers, use of immunotherapy to activate the immune system is currently being considered (Kandalaft et al. 2010).

\section{Prostaglandins}

Prostaglandins are synthesised from arachidonic acid via two isoforms of COX enzymes (termed COX1 and COX2), and much evidence suggests that this signalling pathway contributes to the progression of endometrial adenocarcinoma. High expression of inflammatory COX2 and prostaglandins has been correlated with tumour growth and angiogenesis in several cancer types including prostate, pancreatic and colon cancer (Tsujii et al. 1998, Molina et al. 1999, Jain et al. 2008) and endometrial adenocarcinoma (Tong et al. 2000, Jabbour et al. 2001). Recently, the importance of COX 2 in the early stages of endometrial cancer development was confirmed using a conditional knockout of PTEN in the mouse endometrium (Daikoku et al. 2008). The COX2-prostaglandin pathway has also been linked to $\mathrm{NF} \kappa \mathrm{B}$, as activation of this upregulates COX2 expression and therefore prostaglandin formation (St-Germain et al. 2004).

The prostaglandins $\mathrm{PGE}_{2}$ and $\mathrm{PGF}_{2 \alpha}$ signal through G-protein-coupled receptors named E-prostanoid (EP) and F-prostanoid (FP) receptors respectively. EP receptors exist in four isoforms termed EP1-EP4, and EP2, EP4 and FP receptors have been shown to be elevated in endometrial adenocarcinoma (Jabbour et al. 2001, Sales et al. 2004a,b). Increased prostaglandin signalling through these receptors promotes a number of features associated with the progression of endometrial adenocarcinoma. For example, EP2 and FP receptor activation leads to an increase in the expression of angiogenic genes, including VEGF and FGF (Battersby et al. 2006, Sales et al. 2007). Prostaglandin signalling also promotes cellular changes contributing to cancer progression. $\mathrm{PGF}_{2 \alpha^{-}}$ FP receptor signals via $\mathrm{R}$ ho and $\mathrm{R}$ ac to increase cell migration (Sales et al. 2008a), and both $\mathrm{PGF}_{2 \alpha}$ and $\mathrm{PGE}_{2}$ promote Ishikawa endometrial adenocarcinoma cell proliferation (Jabbour \& Boddy 2003, Sales et al. 2004b). A further link of $\mathrm{PGF}_{2 \alpha}$ to other features of inflammation has recently been demonstrated, as activation of the FP receptor in endometrial adenocarcinoma led to increased chemokine production and thus increased neutrophil infiltration (Wallace et al. 2009). Furthermore, one of the downstream effects of both FP and EP signallings is an increase in COX2 expression (Fujino \& Regan 2003, Sales et al. 2008b); therefore, this positive feedback loop may further amplify prostaglandin signalling in endometrial adenocarcinoma (Jabbour et al. 2005).

Finally, prostaglandins have also been linked to oestrogen signalling. In other pathologies of the endometrium, $\mathrm{PGE}_{2}$ has been shown to increase aromatase expression and therefore oestrogen production. Oestrogen can then upregulate COX2 expression and drive prostaglandin synthesis (Tamura et al. 2002). However, the COX 2 product $\mathrm{PGF}_{2 \alpha}$ causes a downregulation of ESR1, indicating a possible feedback mechanism. Presence of $\mathrm{PGF}_{2 \alpha}$ also prevented the oestrogenmediated upregulation of PGR in Ishikawa endometrial adenocarcinoma cells (Collins et al. 2009). Together, these data

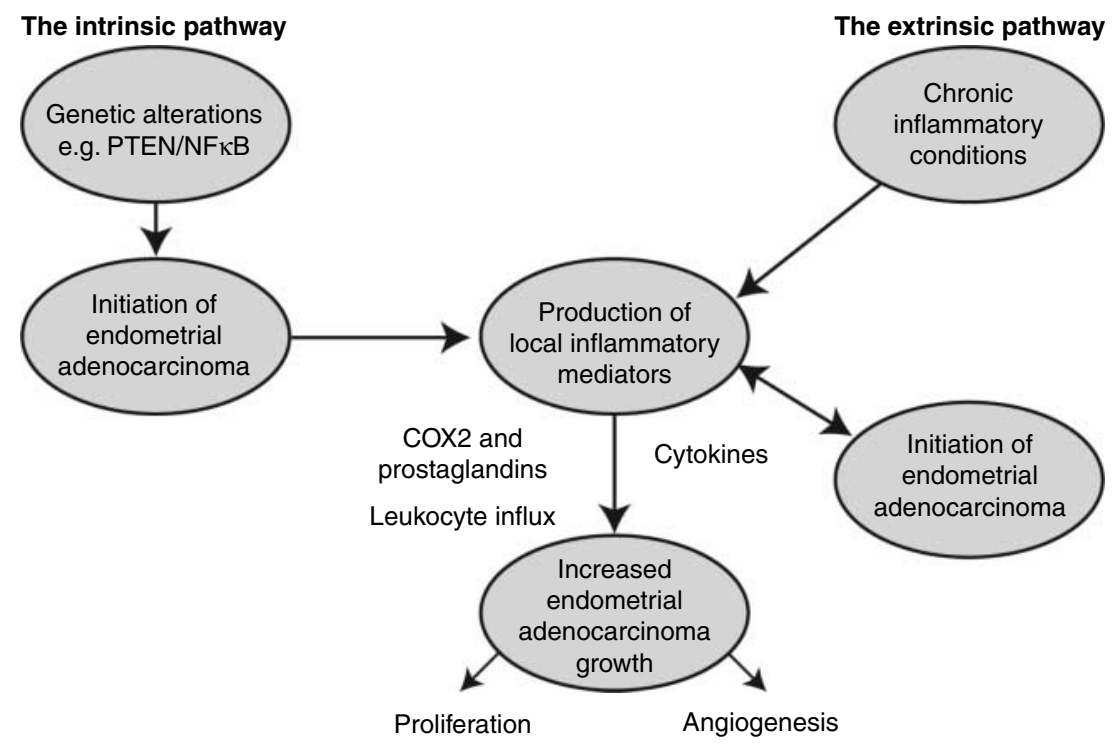

Figure 3 Inflammatory aspects of endometrial adenocarcinoma. Inflammation may contribute to cancer development in different ways. In the intrinsic pathway, after the initiation of cancer by genetic mutations, the expression of inflammatory agents is increased, leading to the promotion of tumour growth. In the extrinsic pathway, current inflammatory conditions lead to the initiation of cancer. In both pathways, further production of inflammatory mediators increases endometrial cancer growth. 
suggest a complex interaction between steroid hormone responsiveness and prostaglandin action in endometrial adenocarcinoma.

\section{Conclusions: endometrial adenocarcinoma and inflammation}

As described earlier, inflammation in cancer is proposed to function by two pathways (Colotta et al. 2009). In the extrinsic pathway, local inflammation promotes malignant transformation of the tissue (Flossmann \& Rothwell 2007, Sandhu 2008). In the intrinsic pathway, genetic changes give rise to cancerous cells, which lead to the upregulation of inflammatory pathways promoting tumour progression and growth. To determine the importance of these hypotheses in endometrial adenocarcinoma, epidemiological evidence can be examined. Endometrial adenocarcinoma displays a number of features of inflammation, such as cytokine expression, leukocyte infiltration and tissue remodelling. In the normal endometrium, the insertion of contraceptive intra-uterine devices promotes a local environment of inflammation, with an infiltration of leukocytes and increase in prostaglandin expression (Srivastava et al. 1989). However, users of this contraceptive method do not display a higher incidence of endometrial adenocarcinoma (Beining et al. 2008). Epidemiological studies have also now been carried out to examine the effects of NSAID use in the development of endometrial adenocarcinoma. In general, these have shown that intake of NSAIDs does not significantly influence the risk of developing endometrial adenocarcinoma (Moysich et al. 2005, Viswanathan et al. 2008, Danforth et al. 2009). This evidence suggests that inflammation in the normal endometrium does not initiate cancer development. However, in subgroups of very obese women, NSAID intake does significantly decrease the risk of endometrial adenocarcinoma development, indicating that the perturbation of inflammatory pathways to the extent found in obesity may contribute to endometrial adenocarcinoma (Viswanathan et al. 2008, Fortuny et al. 2009).

These epidemiological data suggest that in endometrial cancer, it may generally be the intrinsic pathway which is important in the initiation of tumour development. However, the process is evidently complex, and inflammation may contribute to tumour initiation in certain cases, by working in conjunction with other mechanisms (Fortuny et al. 2009). Cancer growth may therefore be initiated by genetic mutations, possibly in endometrial stem cells (Rutella et al. 2009), causing uncontrolled proliferation and subsequent cellular changes. These genetic changes may be a result of increased proliferation driven by an increased oestrogen to progesterone ratio in endometrial adenocarcinoma, in agreement with the unopposed oestrogen hypothesis (Jazaeri et al. 2001). In further support of the intrinsic pathway, a number of genetic mutations such as those of PTEN and Kras have been associated with the development of endometrial adenocarcinoma in women (Enomoto et al. 1990, Tashiro et al. 1997). These mutations have also been associated with the upregulation of inflammatory mediators and activation of the inflammatory transcription factor $\mathrm{NF} \kappa \mathrm{B}$ (St-Germain et al. 2004, Daikoku et al. 2008). Inflammation further facilitates cancer development and the acquisition of more pro-tumourigenic characteristics by cells (Fig. 3).

Until recently, inflammation was thought to resolve passively, by a gradual diminishment of the mediators involved. Now, the role of active biochemical pathways in the resolution of inflammation is recognised, distinct to anti-inflammatory signalling (reviewed in Serhan et al. (2008)). Some of the same lipid mediators which generate inflammatory responses, such as $\mathrm{PGE}_{2}$, can promote the formation of mediators of inflammation resolution, including the lipoxins and resolvins (Serhan et al. 2000). These perform functions such as promoting the clearance of apoptotic leukocytes, and preventing further chemokine expression by these cells (Campbell et al. 2007). In endometrial cancer, the role of these resolution mediators is as yet unknown. Endometrial adenocarcinoma at advanced stages has a poor prognosis (Fleming et al. 2004). Inhibition of inflammation or manipulation of inflammatory resolution pathways may therefore represent a therapeutic target in endometrial adenocarcinoma.

\section{Declaration of interest}

The authors declare that there is no conflict of interest that could be perceived as prejudicing the impartiality of the research reported.

\section{Funding}

The research reported in this review was supported by MRC Human Reproductive Sciences Unit funding to HNJ (U.1276.00.004.00002.01) and PTKS (U1276.00.002.00005.01).

\section{Acknowledgements}

The authors would like to acknowledge the assistance of Ronnie Grant and Ted Pinner in the preparation of graphics files.

\section{References}

Ai S, Cheng XW, Inoue A, Nakamura K, Okumura K, Iguchi A, Murohara T \& Kuzuya M 2007 Angiogenic activity of bFGF and VEGF suppressed by proteolytic cleavage by neutrophil elastase. Biochemical and Biophysical Research Communications 364 395-401.

Akhmedkhanov A, Zeleniuch-Jacquotte A \& Toniolo P 2001 Role of exogenous and endogenous hormones in endometrial cancer: review of the evidence and research perspectives. Annals of the New York Academy of Sciences 943 296-315.

Akiyama M, Okabe H, Takakura K, Fujiyama Y \& Noda Y 1999 Expression of macrophage inflammatory protein-1 $\alpha$ (MIP-1 $\alpha$ ) in human endometrium throughout the menstrual cycle. British Journal of Obstetrics and Gynaecology 106 725-730. 
Albrektsen G, Heuch I, Tretli S \& Kvale G 1995 Is the risk of cancer of the corpus uteri reduced by a recent pregnancy? A prospective study of 765,756 Norwegian women International Journal of Cancer 61 485-490.

Alexander IE, Clarke CL, Shine J \& Sutherland RL 1989 Progestin inhibition of progesterone receptor gene expression in human breast cancer cells. Molecular Endocrinology 3 1377-1386.

Apparao KB, Lovely LP, Gui Y, Lininger RA \& Lessey BA 2002 Elevated endometrial androgen receptor expression in women with polycystic ovarian syndrome. Biology of Reproduction 66 297-304.

Ardi VC, Kupriyanova TA, Deryugina EI \& Quigley JP 2007 Human neutrophils uniquely release TIMP-free MMP-9 to provide a potent catalytic stimulator of angiogenesis. PNAS 104 20262-20267.

Arici A, Seli E, Senturk LM, Gutierrez LS, Oral E \& Taylor HS 1998 Interleukin-8 in the human endometrium. Journal of Clinical Endocrinology and Metabolism 83 1783-1787.

Badoual C, Hans S, Rodriguez J, Peyrard S, Klein C, Agueznay Nel H, Mosseri V, Laccourreye O, Bruneval P, Fridman WH et al. 2006 Prognostic value of tumor-infiltrating $\mathrm{CD} 4+\mathrm{T}$-cell subpopulations in head and neck cancers. Clinical Cancer Research 12 465-472.

Balkwill F \& Mantovani A 2001 Inflammation and cancer: back to Virchow? Lancet 357 539-545.

Bamberger AM, Milde-Langosch K, Loning T \& Bamberger CM 2001 The glucocorticoid receptor is specifically expressed in the stromal compartment of the human endometrium. Journal of Clinical Endocrinology and Metabolism 86 5071-5074.

Barrientos S, Stojadinovic O, Golinko MS, Brem H \& Tomic-Canic M 2008 Growth factors and cytokines in wound healing. Wound Repair and Regeneration 16 585-601.

Battersby S, Sales KJ, Williams AR, Anderson RA, Gardner S \& Jabbour HN 2006 Seminal plasma and prostaglandin $\mathrm{E}_{2}$ up-regulate fibroblast growth factor 2 expression in endometrial adenocarcinoma cells via E-series prostanoid-2 receptor-mediated transactivation of the epidermal growth factor receptor and extracellular signal-regulated kinase pathway. Human Reproduction 22 36-44.

Beining RM, Dennis LK, Smith EM \& Dokras A 2008 Meta-analysis of intrauterine device use and risk of endometrial cancer. Annals of Epidemiology 18 492-499.

Bellone S, Watts K, Cane S, Palmieri M, Cannon MJ, Burnett A, Roman JJ, Pecorelli S \& Santin AD 2005 High serum levels of interleukin-6 in endometrial carcinoma are associated with uterine serous papillary histology, a highly aggressive and chemotherapy-resistant variant of endometrial cancer. Gynecologic Oncology 98 92-98.

Beral V, Bull D \& Reeves G 2005 Endometrial cancer and hormonereplacement therapy in the Million Women Study. Lancet 365 1543-1551.

Bergstrom A, Pisani P, Tenet V, Wolk A \& Adami HO 2001 Overweight as an avoidable cause of cancer in Europe. International Journal of Cancer 91 421-430.

Berry KK, Varney ML, Dave BJ, Bucana CD, Fidler IJ \& Singh RK 2001 Expression of interleukin-8 in human metastatic endometrial carcinoma cells and its regulation by inflammatory cytokines. International Journal of Gynecological Cancer 11 54-60.

Berstein LM, Tchernobrovkina AE, Gamajunova VB, Kovalevskij AJ, Vasilyev DA, Chepik OF, Turkevitch EA, Tsyrlina EV, Maximov SJ, Ashrafian LA et al. 2003 Tumor estrogen content and clinico-morphological and endocrine features of endometrial cancer. Journal of Cancer Research and Clinical Oncology 129 245-249.

Bingle L, Lewis CE, Corke KP, Reed MW \& Brown NJ 2006 Macrophages promote angiogenesis in human breast tumour spheroids in vivo. British Journal of Cancer 94 101-107.

Bokhman JV 1983 Two pathogenetic types of endometrial carcinoma. Gynecologic Oncology 15 10-17.

Bonnotte B, Crittenden M, Larmonier N, Gough N \& Vile RG 2004 MIP-3alpha transfection into a rodent tumor cell line increases intratumoral dendritic cell infiltration but enhances (facilitates) tumor growth and decreases immunogenicity. The Journal of Immunology 173 4929-4935.

Brosens JJ, Lam EW \& Parker MG 2006 Inflammation and sex steroid receptors: a motif for change. Cell 124 466-468.
Bulun SE, Economos K, Miller D \& Simpson ER 1994 CYP19 (aromatase cytochrome P450) gene expression in human malignant endometrial tumors. Journal of Clinical Endocrinology and Metabolism 79 1831-1834.

van der Burg B \& van der Saag PT 1996 Nuclear factor- $\kappa B /$ steroid hormone receptor interactions as a functional basis of anti-inflammatory action of steroids in reproductive organs. Molecular Human Reproduction 2 433-438.

Campbell EL, Louis NA, Tomassetti SE, Canny GO, Arita M, Serhan CN \& Colgan SP 2007 Resolvin E1 promotes mucosal surface clearance of neutrophils: a new paradigm for inflammatory resolution. FASEB Journal 21 3162-3170.

Catasus L, Gallardo A, Cuatrecasas M \& Prat J 2009 Concomitant PI3K-AKT and 53 alterations in endometrial carcinomas are associated with poor prognosis. Modern Pathology 22 522-529.

Chang WC, Huang SC, Torng PL, Chang DY, Hsu WC, Chiou SH, Chow SN \& Sheu BC 2005 Expression of inhibitory natural killer receptors on tumor-infiltrating CD8 + T lymphocyte lineage in human endometrial carcinoma. International Journal of Gynecological Cancer 15 1073-1080.

Chen R, Alvero AB, Silasi DA, Kelly MG, Fest S, Visintin I, Leiser A, Schwartz PE, Rutherford T \& Mor G 2008 Regulation of IKK $\beta$ by miR-199a affects NF- $\kappa B$ activity in ovarian cancer cells. Oncogene $\mathbf{2 7}$ 4712-4723.

Chittenden BG, Fullerton G, Maheshwari A \& Bhattacharya S 2009 Polycystic ovary syndrome and the risk of gynaecological cancer: a systematic review. Reproductive Biomedicine Online 19 398-405.

Choi DS, Kim HJ, Yoon JH, Yoo SC, Jo H, Lee SY, Min CK \& Ryu HS 2009 Endometrial cancer invasion depends on cancer-derived tumor necrosis factor- $\alpha$ and stromal derived hepatocyte growth factor. International Journal of Cancer 124 2528-2538.

Collins F, MacPherson S, Brown P, Bombail V, Williams AR, Anderson RA, Jabbour HN \& Saunders PT 2009 Expression of oestrogen receptors, ER $\alpha$, $\mathrm{ER} \beta$, and $\mathrm{ER} \beta$ variants, in endometrial cancers and evidence that prostaglandin F may play a role in regulating expression of $\mathrm{ER} \alpha . B M C$ Cancer 9330.

Colotta F, Allavena P, Sica A, Garlanda C \& Mantovani A 2009 Cancer-related inflammation, the seventh hallmark of cancer: links to genetic instability. Carcinogenesis 30 1073-1081.

Conti I \& Rollins BJ 2004 CCL2 (monocyte chemoattractant protein-1) and cancer. Seminars in Cancer Biology 14 149-154.

Courtois G \& Gilmore TD 2006 Mutations in the NF- $\kappa B$ signaling pathway: implications for human disease. Oncogene 25 6831-6843.

Couse JF \& Korach KS 1999 Estrogen receptor null mice: what have we learned and where will they lead us? Endocrine Reviews 20 358-417.

Critchley HO \& Saunders PT 2009 Hormone receptor dynamics in a receptive human endometrium. Reproductive Sciences 16 191-199.

Critchley HO, Kelly RW \& Kooy J 1994 Perivascular location of a chemokine interleukin-8 in human endometrium: a preliminary report. Human Reproduction 9 1406-1409.

Critchley HO, Jones RL, Lea RG, Drudy TA, Kelly RW, Williams AR \& Baird DT 1999 Role of inflammatory mediators in human endometrium during progesterone withdrawal and early pregnancy. Journal of Clinical Endocrinology and Metabolism 84 240-248.

Critchley HO, Kelly RW, Brenner RM \& Baird DT 2001a The endocrinology of menstruation - a role for the immune system. Clinical Endocrinology 55 701-710.

Critchley HOD, Brenner RM, Henderson TA, Williams K, Nayak NR, Slayden OD, Millar MR \& Saunders PTK $2001 b$ Estrogen receptor $\beta$, but not estrogen receptor $\alpha$, is present in the vascular endothelium of the human and nonhuman primate endometrium. Journal of Clinical Endocrinology and Metabolism 86 1370-1378.

Cullinan EB, Abbondanzo SJ, Anderson PS, Pollard JW, Lessey BA \& Stewart CL 1996 Leukemia inhibitory factor (LIF) and LIF receptor expression in human endometrium suggests a potential autocrine/paracrine function in regulating embryo implantation. PNAS 93 3115-3120.

Daikoku T, Hirota Y, Tranguch S, Joshi AR, DeMayo FJ, Lydon JP, Ellenson LH \& Dey SK 2008 Conditional loss of uterine Pten unfailingly and rapidly induces endometrial cancer in mice. Cancer Research 68 5619-5627. 
Danforth KN, Gierach GL, Brinton LA, Hollenbeck AR, Katki HA, Leitzmann MF, Schatzkin A \& Lacey JV Jr 2009 Nonsteroidal antiinflammatory drug use and endometrial cancer risk in the NIH-AARP Diet and Health Study. Cancer Prevention Research 2 466-472.

Dannenberg AJ \& Subbaramaiah K 2003 Targeting cyclooxygenase-2 in human neoplasia: rationale and promise. Cancer Cell 4 431-436.

Davies S, Dai D, Feldman I, Pickett G \& Leslie KK 2004 Identification of a novel mechanism of NF- $\mathrm{KB}$ inactivation by progesterone through progesterone receptors in $\mathrm{Hec} 50$ co poorly differentiated endometrial cancer cells: induction of A20 and ABIN-2. Gynecologic Oncology 94 463-470.

Dimitriadis E, Salamonsen LA \& Robb L 2000 Expression of interleukin-11 during the human menstrual cycle: coincidence with stromal cell decidualization and relationship to leukaemia inhibitory factor and prolactin. Molecular Human Reproduction 6 907-914.

Doll A, Abal M, Rigau M, Monge M, Gonzalez M, Demajo S, Colas E, Llaurado M, Alazzouzi H, Planaguma J et al. 2008 Novel molecular profiles of endometrial cancer - new light through old windows. Journal of Steroid Biochemistry and Molecular Biology 108 221-229.

Edwards JP, Zhang X \& Mosser DM 2009 The expression of heparin-binding epidermal growth factor-like growth factor by regulatory macrophages. Journal of Immunology 182 1929-1939.

Ellenson LH \& Wu TC 2004 Focus on endometrial and cervical cancer. Cancer Cell 5 533-538.

Enomoto T, Inoue M, Perantoni AO, Terakawa N, Tanizawa O \& Rice JM $1990 \mathrm{~K}$-ras activation in neoplasms of the human female reproductive tract. Cancer Research 50 6139-6145.

Fainaru O, Adini A, Benny O, Adini I, Short S, Bazinet L, Nakai K, Pravda E, Hornstein MD, D'Amato RJ et al. 2008 Dendritic cells support angiogenesis and promote lesion growth in a murine model of endometriosis. The FASEB Journal 22 522-529.

Ferenczy A, Bertrand G \& Gelfand MM 1979 Proliferation kinetics of human endometrium during the normal menstrual cycle. American Journal of Obstetrics and Gynecology 133 859-867.

Finn CA 1986 Implantation, menstruation and inflammation. Biological Reviews of the Cambridge Philosophical Society 61 313-328.

Fleming GF, Filiaci VL, Bentley RC, Herzog T, Sorosky J, Vaccarello L \& Gallion H 2004 Phase III randomized trial of doxorubicin + cisplatin versus doxorubicin $+24-\mathrm{h}$ paclitaxel + filgrastim in endometrial carcinoma: a Gynecologic Oncology Group Study. Annals of Oncology $151173-1178$

Flossmann E \& Rothwell PM 2007 Commentary: aspirin and colorectal cancer an epidemiological success story. International Journal of Epidemiology 36 962-965.

Fortuny J, Sima C, Bayuga S, Wilcox H, Pulick K, Faulkner S, Zauber AG \& Olson SH 2009 Risk of endometrial cancer in relation to medical conditions and medication use. Cancer Epidemiology, Biomarkers and Prevention 18 1448-1456.

Fujimoto J, Aoki I, Khatun S, Toyoki H \& Tamaya T 2002 Clinical implications of expression of interleukin-8 related to myometrial invasion with angiogenesis in uterine endometrial cancers. Annals of Oncology 13 430-434.

Fujino H \& Regan JW 2003 Prostaglandin $F(2 \alpha)$ stimulation of cyclooxygenase- 2 promoter activity by the $\mathrm{FP}(\mathrm{B})$ prostanoid receptor. European Journal of Pharmacology 465 39-41.

Gabrilovich D, Ishida T, Oyama T, Ran S, Kravtsov V, Nadaf S \& Carbone DP 1998 Vascular endothelial growth factor inhibits the development of dendritic cells and dramatically affects the differentiation of multiple hematopoietic lineages in vivo. Blood 92 4150-4166.

Gargett CE, Lederman F, Heryanto B, Gambino LS \& Rogers PA 2001 Focal vascular endothelial growth factor correlates with angiogenesis in human endometrium. Role of intravascular neutrophils. Human Reproduction $\mathbf{1 6}$ 1065-1075.

Gates EJ, Hirschfield L, Matthews RP \& Yap OW 2006 Body mass index as a prognostic factor in endometrioid adenocarcinoma of the endometrium. Journal of the National Medical Association 98 1814-1822.
Gelmini S, Mangoni M, Castiglione F, Beltrami C, Pieralli A, Andersson KL, Fambrini M, Taddei GL, Serio M \& Orlando C 2009 The CXCR4/CXCL12 axis in endometrial cancer. Clinical and Experimental Metastasis 26 261-268.

Giatromanolaki A, Bates GJ, Koukourakis MI, Sivridis E, Gatter KC, Harris AL \& Banham AH 2008 The presence of tumor-infiltrating FOXP3 + lymphocytes correlates with intratumoral angiogenesis in endometrial cancer. Gynecologic Oncology 110 216-221.

Giudice LC 2006 Endometrium in PCOS: implantation and predisposition to endocrine CA. Best Practice \& Research. Clinical Endocrinology and Metabolism $20235-244$

Gori F, Hofbauer LC, Conover CA \& Khosla S 1999 Effects of androgens on the insulin-like growth factor system in an androgen-responsive human osteoblastic cell line. Endocrinology 140 5579-5586.

Grady D, Gebretsadik T, Kerlikowske K, Ernster V \& Petitti D 1995 Hormone replacement therapy and endometrial cancer risk: a meta-analysis. Obstetrics and Gynecology 85 304-313.

Greten FR, Eckmann L, Greten TF, Park JM, Li ZW, Egan LJ, Kagnoff MF \& Karin M 2004 IKK $\beta$ links inflammation and tumorigenesis in a mouse model of colitis-associated cancer. Cell 118 285-296.

Hachisuga T, Fukuda K, Nakamura S, Iwasaka T \& Sugimori H 1997 Local immune response in endometrial carcinomas. British Journal of Obstetrics and Gynaecology 104 110-114.

Haghnegahdar H, Du J, Wang D, Strieter RM, Burdick MD, Nanney LB, Cardwell N, Luan J, Shattuck-Brandt R \& Richmond A 2000 The tumorigenic and angiogenic effects of MGSA/GRO proteins in melanoma. Journal of Leukocyte Biology 67 53-62.

Hale GE, Hughes CL \& Cline JM 2002 Endometrial cancer: hormonal factors, the perimenopausal "window of risk," and isoflavones. Journal of Clinical Endocrinology and Metabolism 87 3-15.

Hall JM \& McDonnell DP 1999 The estrogen receptor $\beta$-isoform (ER $\beta$ ) of the human estrogen receptor modulates ER $\alpha$ transcriptional activity and is a key regulator of the cellular response to estrogens and antiestrogens. Endocrinology 140 5566-5578.

Hanekamp EE, Gielen SC, Smid-Koopman E, Kuhne LC, de Ruiter PE, Chadha-Ajwani S, Brinkmann AO, Grootegoed JA, Burger CW, Huikeshoven FJ et al. 2003 Consequences of loss of progesterone receptor expression in development of invasive endometrial cancer. Clinical Cancer Research 9 4190-4199.

Harrison ML, Obermueller E, Maisey NR, Hoare S, Edmonds K, Li NF, Chao D, Hall K, Lee C, Timotheadou E et al. 2007 Tumor necrosis factor $\alpha$ as a new target for renal cell carcinoma: two sequential phase II trials of infliximab at standard and high dose. Journal of Clinical Oncology 25 4542-4549.

Hastings JM, Licence DR, Burton GJ, Charnock-Jones DS \& Smith SK 2003 Soluble vascular endothelial growth factor receptor 1 inhibits edema and epithelial proliferation induced by $17 \beta$-estradiol in the mouse uterus. Endocrinology 144 326-334.

Hayakawa Y, Takeda K, Yagita H, Smyth MJ, Van Kaer L, Okumura K \& Saiki I 2002 IFN-gamma-mediated inhibition of tumor angiogenesis by natural killer T-cell ligand, alpha-galactosylceramide. Blood 100 1728-1733.

He YY, Cai B, Yang YX, Liu XL \& Wan XP 2009 Estrogenic G protein-coupled receptor 30 signaling is involved in regulation of endometrial carcinoma by promoting proliferation, invasion potential, and interleukin-6 secretion via the MEK/ERK mitogen-activated protein kinase pathway. Cancer Science 100 1051-1061.

Hendrickson M, Ross J, Eifel P, Martinez A \& Kempson R 1982 Uterine papillary serous carcinoma: a highly malignant form of endometrial adenocarcinoma. American Journal of Surgical Pathology 693-108.

Hornung D, Ryan IP, Chao VA, Vigne JL, Schriock ED \& Taylor RN 1997 Immunolocalization and regulation of the chemokine RANTES in human endometrial and endometriosis tissues and cells. Journal of Clinical Endocrinology and Metabolism 82 1621-1628.

Horwitz KB \& McGuire WL 1978 Estrogen control of progesterone receptor in human breast cancer. Correlation with nuclear processing of estrogen receptor. Journal of Biological Chemistry 253 2223-2228. 
Ishihara O, Matsuoka K, Kinoshita K, Sullivan MH \& Elder MG 1995 Interleukin-1 $\beta$-stimulated $\mathrm{PGE}_{2}$ production from early first trimester human decidual cells is inhibited by dexamethasone and progesterone. Prostaglandins 49 15-26.

Ito A, Imada K, Sato T, Kubo T, Matsushima K \& Mori Y 1994 Suppression of interleukin 8 production by progesterone in rabbit uterine cervix. Biochemical Journal 301 183-186.

Ito K, Suzuki T, Akahira J, Moriya T, Kaneko C, Utsunomiya H, Yaegashi N, Okamura K \& Sasano H 2002 Expression of androgen receptor and $5 \alpha$-reductases in the human normal endometrium and its disorders. International Journal of Cancer 99 652-657.

Ito K, Utsunomiya H, Yaegashi N \& Sasano H 2007 Biological roles of estrogen and progesterone in human endometrial carcinoma - new developments in potential endocrine therapy for endometrial cancer. Endocrine Journal 54 667-679.

Jabbour HN \& Boddy SC 2003 Prostaglandin $E_{2}$ induces proliferation of glandular epithelial cells of the human endometrium via extracellular regulated kinase 1/2-mediated pathway. Journal of Clinical Endocrinology and Metabolism 88 4481-4487.

Jabbour HN, Milne SA, Williams AR, Anderson RA \& Boddy SC 2001 Expression of COX-2 and PGE synthase and synthesis of PGE(2)in endometrial adenocarcinoma: a possible autocrine/paracrine regulation of neoplastic cell function via EP2/EP4 receptors. British Journal of Cancer $\mathbf{8 5}$ 1023-1031.

Jabbour HN, Sales KJ, Boddy SC, Anderson RA \& Williams AR 2005 A positive feedback loop that regulates cyclooxygenase-2 expression and prostaglandin $\mathrm{F}_{2 \alpha}$ synthesis via the $\mathrm{F}$-series-prostanoid receptor and extracellular signal-regulated kinase 1/2 signaling pathway. Endocrinology 146 4657-4664.

Jabbour HN, Kelly RW, Fraser HM \& Critchley HO 2006 Endocrine regulation of menstruation. Endocrine Reviews 27 17-46.

Jacobs AL, Sehgal PB, Julian J \& Carson DD 1992 Secretion and hormonal regulation of interleukin-6 production by mouse uterine stromal and polarized epithelial cells cultured in vitro. Endocrinology 131 1037-1046.

Jain S, Chakraborty G, Raja R, Kale S \& Kundu GC 2008 Prostaglandin $E_{2}$ regulates tumor angiogenesis in prostate cancer. Cancer Research $\mathbf{6 8}$ 7750-7759

Jazaeri AA, Nunes KJ, Dalton MS, Xu M, Shupnik MA \& Rice LW 2001 Well-differentiated endometrial adenocarcinomas and poorly differentiated mixed mullerian tumors have altered $\mathrm{ER}$ and $\mathrm{PR}$ isoform expression. Oncogene 20 6965-6969.

Jones RL, Kelly RW \& Critchley HO 1997 Chemokine and cyclooxygenase2 expression in human endometrium coincides with leukocyte accumulation. Human Reproduction 12 1300-1306.

Ju W \& Kim SC 2007 Polymorphisms in CAG active allele length of the androgen receptor gene are not associated with increased risk of endometrial cancer. Cancer Genetics and Cytogenetics 172 178-179.

Kaitu'u-Lino TJ, Morison NB \& Salamonsen LA 2007 Neutrophil depletion retards endometrial repair in a mouse model. Cell and Tissue Research $\mathbf{3 2 8}$ 197-206.

Kalandidi A, Tzonou A, Lipworth L, Gamatsi I, Filippa D \& Trichopoulos D 1996 A case-control study of endometrial cancer in relation to reproductive, somatometric, and life-style variables. Oncology 53 354-359.

Kandalaft LE, Singh N, Liao JB, Facciabene A, Berek JS, Powell DJ Jr \& Coukos G 2010 The emergence of immunomodulation: combinatorial immunochemotherapy opportunities for the next decade. Gynecologic Oncology 116 222-233.

Karageorgi S, Hankinson SE, Kraft P \& De Vivo I 2010 Reproductive factors and postmenopausal hormone use in relation to endometrial cancer risk in the Nurses' Health Study cohort 1976-2004. International Journal of Cancer 126 208-216.

Kashima H, Shiozawa T, Miyamoto T, Suzuki A, Uchikawa J, Kurai M \& Konishi I 2009 Autocrine stimulation of IGF1 in estrogen-induced growth of endometrial carcinoma cells: involvement of the mitogen-activated protein kinase pathway followed by up-regulation of cyclin D1 and cyclin E. Endocrine-Related Cancer 16 113-122.
Keane MP, Belperio JA, Xue YY, Burdick MD \& Strieter RM 2004 Depletion of CXCR2 inhibits tumor growth and angiogenesis in a murine model of lung cancer. Journal of Immunology 172 2853-2860.

Kelly RW, Illingworth P, Baldie G, Leask R, Brouwer S \& Calder AA 1994 Progesterone control of interleukin-8 production in endometrium and chorio-decidual cells underlines the role of the neutrophil in menstruation and parturition. Human Reproduction 9 253-258.

Kelly RW, Carr GG \& Riley SC 1997 The inhibition of synthesis of a $\beta$-chemokine, monocyte chemotactic protein-1 (MCP-1) by progesterone. Biochemical and Biophysical Research Communications 239 557-561.

King AE, Collins F, Klonisch T, Sallenave JM, Critchley HO \& Saunders PT 2009 An additive interaction between the NFKB and estrogen receptor signalling pathways in human endometrial epithelial cells. Human Reproduction 25 510-518.

Kohler MF, Berchuck A, Davidoff AM, Humphrey PA, Dodge RK, Iglehart JD, Soper JT, Clarke-Pearson DL, Bast RC Jr \& Marks JR 1992 Overexpression and mutation of p53 in endometrial carcinoma. Cancer Research 52 1622-1627.

Kondratiev S, Sabo E, Yakirevich E, Lavie O \& Resnick MB 2004 Intratumoral CD8 + T lymphocytes as a prognostic factor of survival in endometrial carcinoma. Clinical Cancer Research 10 4450-4456.

Lavergne E, Combadiere C, Iga M, Boissonnas A, Bonduelle O, Maho M, Debre P \& Combadiere B 2004 Intratumoral CC chemokine ligand 5 overexpression delays tumor growth and increases tumor cell infiltration. Journal of Immunology 173 3755-3762.

Lax SF, Kendall B, Tashiro H, Slebos RJ \& Hedrick L 2000 The frequency of p53, K-ras mutations, and microsatellite instability differs in uterine endometrioid and serous carcinoma: evidence of distinct molecular genetic pathways. Cancer 88 814-824.

Lee LF, Hellendall RP, Wang Y, Haskill JS, Mukaida N, Matsushima K \& Ting JP 2000 IL-8 reduced tumorigenicity of human ovarian cancer in vivo due to neutrophil infiltration. Journal of Immunology 164 2769-2775.

Lin EY, Nguyen AV, Russell RG \& Pollard JW 2001 Colony-stimulating factor 1 promotes progression of mammary tumors to malignancy. Journal of Experimental Medicine 193 727-740.

Lin YJ, Lai MD, Lei HY \& Wing LY 2006 Neutrophils and macrophages promote angiogenesis in the early stage of endometriosis in a mouse model. Endocrinology 147 1278-1286.

Loberg RD, Ying C, Craig M, Day LL, Sargent E, Neeley C, Wojno K, Snyder LA, Yan L \& Pienta KJ 2007 Targeting CCL2 with systemic delivery of neutralizing antibodies induces prostate cancer tumor regression in vivo. Cancer Research 67 9417-9424.

Lovely LP, Appa Rao KBC, Gui Y \& Lessey BA 2000 Characterization of androgen receptors in a well-differentiated endometrial adenocarcinoma cell line (Ishikawa). Journal of Steroid Biochemistry and Molecular Biology $\mathbf{7 4}$ 235-241.

Lydon JP, DeMayo FJ, Funk CR, Mani SK, Hughes AR, Montgomery CA Jr, Shyamala G, Conneely OM \& O'Malley BW 1995 Mice lacking progesterone receptor exhibit pleiotropic reproductive abnormalities. Genes and Development 9 2266-2278.

Maehama T \& Dixon JE 1998 The tumor suppressor, PTEN/MMAC1, dephosphorylates the lipid second messenger, phosphatidylinositol 3,4,5trisphosphate. Journal of Biological Chemistry 273 13375-13378.

Mantovani A, Savino B, Locati M, Zammataro L, Allavena P \& Bonecchi R 2009 The chemokine system in cancer biology and therapy. Cytokine and Growth Factor Reviews 21 27-39.

Martucci C \& Fishman J 1977 Direction of estradiol metabolism as a control of its hormonal action-uterotrophic activity of estradiol metabolites. Endocrinology 101 1709-1715.

Marwood M, Visser K, Salamonsen LA \& Dimitriadis E 2009 Interleukin-11 and leukemia inhibitory factor regulate the adhesion of endometrial epithelial cells: implications in fertility regulation. Endocrinology $\mathbf{1 5 0}$ 2915-2923.

McDonald SE, Henderson TA, Gomez-Sanchez CE, Critchley HO \& Mason JI 2006 11ß-Hydroxysteroid dehydrogenases in human endometrium. Molecular and Cellular Endocrinology 248 72-78. 
McGrath M, Lee IM, Hankinson SE, Kraft P, Hunter DJ, Buring J \& De Vivo I 2006 Androgen receptor polymorphisms and endometrial cancer risk. International Journal of Cancer 118 1261-1268.

Michnovicz JJ, Hershcopf RJ, Naganuma H, Bradlow HL \& Fishman J 1986 Increased 2-hydroxylation of estradiol as a possible mechanism for the antiestrogenic effect of cigarette smoking. New England Journal of Medicine $\mathbf{3 1 5}$ 1305-1309.

Miyatake T, Tringler B, Liu W, Liu SH, Papkoff J, Enomoto T, Torkko KC, Dehn DL, Swisher A \& Shroyer KR 2007 B7-H4 (DD-O110) is overexpressed in high risk uterine endometrioid adenocarcinomas and inversely correlated with tumor T-cell infiltration. Gynecologic Oncology 106 $119-127$.

Mizumoto Y, Kyo S, Mori N, Sakaguchi J, Ohno S, Maida Y, Hashimoto M, Takakura M \& Inoue M 2007 Activation of ERK1/2 occurs independently of KRAS or BRAF status in endometrial cancer and is associated with favorable prognosis. Cancer Science 98 652-658.

Modugno F, Ness RB, Chen C \& Weiss NS 2005 Inflammation and endometrial cancer: a hypothesis. Cancer Epidemiology, Biomarkers and Prevention 14 2840-2847.

Molina MA, Sitja-Arnau M, Lemoine MG, Frazier ML \& Sinicrope FA 1999 Increased cyclooxygenase-2 expression in human pancreatic carcinomas and cell lines: growth inhibition by nonsteroidal anti-inflammatory drugs. Cancer Research 59 4356-4362.

Moysich KB, Baker JA, Rodabaugh KJ \& Villella JA 2005 Regular analgesic use and risk of endometrial cancer. Cancer Epidemiology, Biomarkers and Prevention 14 2923-2928.

Murphy PM, Baggiolini M, Charo IF, Hebert CA, Horuk R, Matsushima K, Miller LH, Oppenheim JJ \& Power CA 2000 International union of pharmacology. XXII. Nomenclature for chemokine receptors. Pharmacological Reviews 52 145-176.

Nilsson BO 2007 Modulation of the inflammatory response by estrogens with focus on the endothelium and its interactions with leukocytes. Inflammation Research 56 269-273.

Nishimura T, Iwakabe K, Sekimoto M, Ohmi Y, Yahata T, Nakui M, Sato T, Habu S, Tashiro H, Sato M et al. 1999 Distinct role of antigen-specific T helper type 1 (Th1) and Th2 cells in tumor eradication in vivo. Journal of Experimental Medicine 190 617-627.

Oh JH, Kim JH, Ahn HJ, Yoon JH, Yoo SC, Choi DS, Lee IS, Ryu HS \& Min CK 2009 Syndecan-1 enhances the endometrial cancer invasion by modulating matrix metalloproteinase-9 expression through nuclear factor кB. Gynecologic Oncology 114 509-515.

Ohno S, Ohno Y, Suzuki N, Kamei T, Koike K, Inagawa H, Kohchi C, Soma G \& Inoue M 2004 Correlation of histological localization of tumor-associated macrophages with clinicopathological features in endometrial cancer. Anticancer Research 24 3335-3342.

Ohno Y, Ohno S, Suzuki N, Kamei T, Inagawa H, Soma G \& Inoue M 2005 Role of cyclooxygenase-2 in immunomodulation and prognosis of endometrial carcinoma. International Journal of Cancer 114 696-701.

Ohno S, Ohno Y, Nakada H, Suzuki N, Soma G \& Inoue M 2006 Expression of $\mathrm{Tn}$ and sialyl-Tn antigens in endometrial cancer: its relationship with tumor-produced cyclooxygenase-2, tumor-infiltrated lymphocytes and patient prognosis. Anticancer Research 26 4047-4053.

Paech K, Webb P, Kuiper GG, Nilsson S, Gustafsson J, Kushner PJ \& Scanlan TS 1997 Differential ligand activation of estrogen receptors $\mathrm{ER} \alpha$ and $\mathrm{ER} \beta$ at AP1 sites. Science 277 1508-1510.

Pakrasi PL \& Tiwari A 2007 Evidence of increased endometrial vascular permeability at the time of implantation in the short-nosed fruit bat, Cyanopterus sphinx. Animal Reproduction Science 101 179-185.

Pallares J, Martinez-Guitarte JL, Dolcet X, Llobet D, Rue M, Palacios J, Prat J \& Matias-Guiu X 2004 Abnormalities in the NF- $\kappa$ B family and related proteins in endometrial carcinoma. Journal of Pathology 204 569-577.

Palucka K, Ueno H, Zurawski G, Fay J \& Banchereau J 2010 Building on dendritic cell subsets to improve cancer vaccines. Current Opinion in Immunology 22 258-263.

Pole JC, Gold LI, Orton T, Huby R \& Carmichael PL 2005 Gene expression changes induced by estrogen and selective estrogen receptor modulators in primary-cultured human endometrial cells: signals that distinguish the human carcinogen tamoxifen. Toxicology 206 91-109.
Pomerantz JL \& Baltimore D 2002 Two pathways to NF-кB. Molecular Cell 10 693-695.

Popivanova BK, Kostadinova FI, Furuichi K, Shamekh MM, Kondo T, Wada T, Egashira K \& Mukaida N 2009 Blockade of a chemokine, CCL2, reduces chronic colitis - associated carcinogenesis in mice. Cancer Research $697884-7892$.

Purohit A \& Reed MJ 2002 Regulation of estrogen synthesis in postmenopausal women. Steroids 67 979-983.

Purohit A, Singh A, Ghilchik MW \& Reed MJ 1999 Inhibition of tumor necrosis factor $\boldsymbol{\alpha}$-stimulated aromatase activity by microtubule-stabilizing agents, paclitaxel and 2-methoxyestradiol. Biochemical and Biophysical Research Communications 261 214-217.

Reeves GK, Pirie K, Beral V, Green J, Spencer E \& Bull D 2007 Cancer incidence and mortality in relation to body mass index in the Million Women Study: cohort study. BMJ 3351134.

Rieck G \& Fiander A 2006 The effect of lifestyle factors on gynaecological cancer. Best Practice \& Research. Clinical Obstetrics \& Gynaecology 20 227-251.

Rowe AJ, Wulff C \& Fraser HM 2003 Localization of mRNA for vascular endothelial growth factor (VEGF), angiopoietins and their receptors during the peri-implantation period and early pregnancy in marmosets (Callithrix jacchus). Reproduction 126 227-238.

Rutella S, Bonanno G, Procoli A, Mariotti A, Corallo M, Prisco MG, Eramo A, Napoletano C, Gallo D, Perillo A et al. 2009 Cells with characteristics of cancer stem/progenitor cells express the CD133 antigen in human endometrial tumors. Clinical Cancer Research 15 4299-4311.

Sahlin L, Norstedt G \& Eriksson H 1994 Androgen regulation of the insulin-like growth factor-I and the estrogen receptor in rat uterus and liver. Journal of Steroid Biochemistry and Molecular Biology 51 57-66.

Salama SA, Kamel MW, Diaz-Arrastia CR, Xu X, Veenstra TD, Salih S, Botting SK \& Kumar R 2009 Effect of tumor necrosis factor- $\alpha$ on estrogen metabolism and endometrial cells: potential physiological and pathological relevance. Journal of Clinical Endocrinology and Metabolism 94 285-293.

Salamonsen LA 2003 Tissue injury and repair in the female human reproductive tract. Reproduction 125 301-311.

Sales KJ, Grant V, Cook IH, Maldonado-Perez D, Anderson RA, Williams AR \& Jabbour HN 2010 Interleukin-11 in endometrial adenocarcinoma is regulated by prostaglandin F2alpha-F-prostanoid receptor interaction via the calcium-calcineurin-nuclear factor of activated $\mathrm{T}$ cells pathway and negatively regulated by the regulator of calcineurin-1. American Journal of Pathology 176 435-445.

Sales KJ, Maudsley S \& Jabbour HN 2004a Elevated prostaglandin EP2 receptor in endometrial adenocarcinoma cells promotes vascular endothelial growth factor expression via cyclic 3', 5'-adenosine monophosphate-mediated transactivation of the epidermal growth factor receptor and extracellular signal-regulated kinase $1 / 2$ signaling pathways. Molecular Endocrinology 18 1533-1545.

Sales KJ, Milne SA, Williams AR, Anderson RA \& Jabbour HN $2004 b$ Expression, localization, and signaling of prostaglandin $\mathrm{F}_{2 \alpha}$ receptor in human endometrial adenocarcinoma: regulation of proliferation by activation of the epidermal growth factor receptor and mitogen-activated protein kinase signaling pathways. Journal of Clinical Endocrinology and Metabolism 89 986-993.

Sales KJ, List T, Boddy SC, Williams AR, Anderson RA, Naor Z \& Jabbour HN 2005 A novel angiogenic role for prostaglandin F2alpha-FP receptor interaction in human endometrial adenocarcinomas. Cancer Research $\mathbf{6 5}$ 7707-7716.

Sales KJ, Boddy SC, Williams AR, Anderson RA \& Jabbour HN 2007 F-prostanoid receptor regulation of fibroblast growth factor 2 signaling in endometrial adenocarcinoma cells. Endocrinology 148 3635-3644.

Sales KJ, Boddy SC \& Jabbour HN 2008a F-prostanoid receptor alters adhesion, morphology and migration of endometrial adenocarcinoma cells. Oncogene 27 2466-2477.

Sales KJ, Grant V \& Jabbour HN $2008 b$ Prostaglandin $\mathrm{E}_{2}$ and $\mathrm{F}_{2 \alpha}$ activate the FP receptor and up-regulate cyclooxygenase-2 expression via the cyclic AMP response element. Molecular and Cellular Endocrinology 285 51-61. 
Salvesen HB \& Akslen LA 1999 Significance of tumour-associated macrophages, vascular endothelial growth factor and thrombospondin-1 expression for tumour angiogenesis and prognosis in endometrial carcinomas. International Journal of Cancer 84 538-543.

Sandhu JS 2008 Prostate cancer and chronic prostatitis. Current Urology Reports 9 328-332.

Sauve K, Lepage J, Sanchez M, Heveker N \& Tremblay A 2009 Positive feedback activation of estrogen receptors by the CXCL12-CXCR 4 pathway. Cancer Research 69 5793-5800.

Scapini P, Morini M, Tecchio C, Minghelli S, Di Carlo E, Tanghetti E, Albini A, Lowell C, Berton G, Noonan DM et al. 2004 CXCL1/macrophage inflammatory protein-2-induced angiogenesis in vivo is mediated by neutrophil-derived vascular endothelial growth factor-A. Journal of Immunology 172 5034-5040.

Schultz G, Rotatori DS \& Clark W 1991 EGF and TGF- $\alpha$ in wound healing and repair. Journal of Cellular Biochemistry 45 346-352.

Schutyser E, Struyf S \& Van Damme J 2003 The CC chemokine CCL20 and its receptor CCR6. Cytokine \& Growth Factor Reviews 14 409-426.

Seo KH, Lee HS, Jung B, Ko HM, Choi JH, Park SJ, Choi IH, Lee HK \& Im SY 2004 Estrogen enhances angiogenesis through a pathway involving platelet-activating factor-mediated nuclear factor- $\mathrm{\kappa B}$ activation. Cancer Research 64 6482-6488.

Serhan CN, Clish CB, Brannon J, Colgan SP, Gronert K \& Chiang N 2000 Anti-microinflammatory lipid signals generated from dietary N-3 fatty acids via cyclooxygenase-2 and transcellular processing: a novel mechanism for NSAID and N-3 PUFA therapeutic actions. Journal of Physiology and Pharmacology 51 643-654.

Serhan CN, Chiang N \& Van Dyke TE 2008 Resolving inflammation: dual anti-inflammatory and pro-resolution lipid mediators. Nature Reviews. Immunology 8 349-361.

Singh S, Sadanandam A, Nannuru KC, Varney ML, Mayer-Ezell R, Bond R \& Singh RK 2009a Small-molecule antagonists for CXCR2 and CXCR1 inhibit human melanoma growth by decreasing tumor cell proliferation, survival, and angiogenesis. Clinical Cancer Research $\mathbf{1 5}$ 2380-2386.

Singh S, Varney M \& Singh RK $2009 b$ Host CXCR2-dependent regulation of melanoma growth, angiogenesis, and experimental lung metastasis. Cancer Research 69 411-415.

Slater M, Cooper M \& Murphy CR 2006 Human growth hormone and interleukin-6 are upregulated in endometriosis and endometrioid adenocarcinoma. Acta Histochemica 108 13-18.

Smyth MJ, Crowe NY \& Godfrey DI 2001 NK cells and NKT cells collaborate in host protection from methylcholanthrene-induced fibrosarcoma. International Immunology 13 459-463.

Soeda S, Nakamura N, Ozeki T, Nishiyama H, Hojo H, Yamada H, Abe M \& Sato A 2008 Tumor-associated macrophages correlate with vascular space invasion and myometrial invasion in endometrial carcinoma. Gynecologic Oncology 109 122-128.

Sparmann A \& Bar-Sagi D 2004 Ras-induced interleukin-8 expression plays a critical role in tumor growth and angiogenesis. Cancer Cell $\mathbf{6}$ 447-458.

Srivastava K, Dasgupta PK, Srivastava AK \& Murthy PS 1989 Role of plasminogen activators and leukocytes in IUD-induced inflammation: effect of some anti-inflammatory agents. Advances in Contraception $\mathbf{5}$ 173-178.

St-Germain ME, Gagnon V, Parent S \& Asselin E 2004 Regulation of COX-2 protein expression by Akt in endometrial cancer cells is mediated through

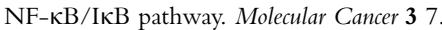

Straub RH 2007 The complex role of estrogens in inflammation. Endocrine Reviews 28 521-574.

Strieter RM, Polverini PJ, Kunkel SL, Arenberg DA, Burdick MD, Kasper J, Dzuiba J, Van Damme J, Walz A, Marriott D et al. 1995 The functional role of the ELR motif in CXC chemokine-mediated angiogenesis. Journal of Biological Chemistry $27027348-27357$.

Suzuki H, Iwasaki E \& Hibi T 2009 Helicobacter pylori and gastric cancer. Gastric Cancer 12 79-87.
Tabibzadeh S, Kong QF, Babaknia A \& May LT 1995 Progressive rise in the expression of interleukin-6 in human endometrium during menstrual cycle is initiated during the implantation window. Human Reproduction $102793-2799$

Tamura M, Sebastian S, Yang S, Gurates B, Ferrer K, Sasano H, Okamura K \& Bulun SE 2002 Up-regulation of cyclooxygenase-2 expression and prostaglandin synthesis in endometrial stromal cells by malignant endometrial epithelial cells. A paracrine effect mediated by prostaglandin $\mathrm{E}_{2}$ and nuclear factor- $\mathrm{KB}$. Journal of Biological Chemistry 277 26208-26216.

Tanaka Y, Kobayashi H, Suzuki M, Kanayama N, Suzuki M \& Terao T 2002 Thymidine phosphorylase expression in tumor-infiltrating macrophages may be correlated with poor prognosis in uterine endometrial cancer. Human Pathology 33 1105-1113.

Tashiro H, Blazes MS, Wu R, Cho KR, Bose S, Wang SI, Li J, Parsons R \& Ellenson LH 1997 Mutations in PTEN are frequent in endometrial carcinoma but rare in other common gynecological malignancies. Cancer Research 57 3935-3940.

Tazawa H, Okada F, Kobayashi T, Tada M, Mori Y, Une Y, Sendo F, Kobayashi M \& Hosokawa M 2003 Infiltration of neutrophils is required for acquisition of metastatic phenotype of benign murine fibrosarcoma cells: implication of inflammation-associated carcinogenesis and tumor progression. American Journal of Pathology 163 2221-2232.

Tong BJ, Tan J, Tajeda L, Das SK, Chapman JA, DuBois RN \& Dey SK 2000 Heightened expression of cyclooxygenase-2 and peroxisome proliferatoractivated receptor-delta in human endometrial adenocarcinoma. Neoplasia 2 483-490.

Tsujii M, Kawano S, Tsuji S, Sawaoka H, Hori M \& DuBois RN 1998 Cyclooxygenase regulates angiogenesis induced by colon cancer cells. Cell 93 705-716.

Tsukamoto H, Shibata K, Kajiyama H, Terauchi M, Nawa A \& Kikkawa F 2007 Uterine smooth muscle cells increase invasive ability of endometrial carcinoma cells through tumor-stromal interaction. Clinical \& Experimental Metastasis 24 423-429.

Uutela M, Wirzenius M, Paavonen K, Rajantie I, He Y, Karpanen T, Lohela M, Wiig H, Salven P, Pajusola K et al. 2004 PDGF-D induces macrophage recruitment, increased interstitial pressure, and blood vessel maturation during angiogenesis. Blood 104 3198-3204.

Vani S, Critchley HO, Fraser IS \& Hickey M 2008 Endometrial expression of steroid receptors in postmenopausal hormone replacement therapy users: relationship to bleeding patterns. Journal of Family Planning and Reproductive Health Care 34 27-34.

Venneri MA, De Palma M, Ponzoni M, Pucci F, Scielzo C, Zonari E, Mazzieri R, Doglioni C \& Naldini L 2007 Identification of proangiogenic TIE2-expressing monocytes (TEMs) in human peripheral blood and cancer. Blood 109 5276-5285.

de Visser KE, Eichten A \& Coussens LM 2006 Paradoxical roles of the immune system during cancer development. Nature Reviews. Cancer 6 24-37.

Viswanathan AN, Feskanich D, Schernhammer ES \& Hankinson SE 2008 Aspirin, NSAID, and acetaminophen use and the risk of endometrial cancer. Cancer Research 68 2507-2513.

Wallace AE, Sales KJ, Catalano RD, Anderson RA, Williams AR, Wilson MR, Schwarze J, Wang H, Rossi AG \& Jabbour HN 2009 Prostaglandin $\mathrm{F}_{2 \alpha}$-F-prostanoid receptor signaling promotes neutrophil chemotaxis via chemokine (C-X-C motif) ligand 1 in endometrial adenocarcinoma. Cancer Research 69 5726-5733.

Wang B, Hendricks DT, Wamunyokoli F \& Parker MI 2006a A growth-related oncogene/CXC chemokine receptor 2 autocrine loop contributes to cellular proliferation in esophageal cancer. Cancer Research 66 3071-3077.

Wang L, Zheng W, Zhang S, Chen X \& Hornung D $2006 b$ Expression of monocyte chemotactic protein-1 in human endometrial cancer cells and the effect of treatment with tamoxifen or buserelin. Journal of International Medical Research 34 284-290.

Wang L, Liu Q, Sun Q, Zhang C, Chen T \& Cao X 2008 TLR4 signaling in cancer cells promotes chemoattraction of immature dendritic cells via autocrine CCL20. Biochemical and Biophysical Research Communications 366 $852-856$ 
Wong YF, Cheung TH, Lo KW, Yim SF, Siu NS, Chan SC, Ho TW, Wong KW, Yu MY, Wang VW et al. 2007 Identification of molecular markers and signaling pathway in endometrial cancer in Hong Kong Chinese women by genome-wide gene expression profiling. Oncogene $\mathbf{2 6}$ 1971-1982.

Yamamoto M, Kikuchi H, Ohta M, Kawabata T, Hiramatsu Y, Kondo K, Baba M, Kamiya K, Tanaka T, Kitagawa M et al. 2008 TSU68 prevents liver metastasis of colon cancer xenografts by modulating the premetastatic niche. Cancer Research 68 9754-9762.

Yamazawa K, Seki K, Matsui H \& Sekiya S 2001 Significance of perivascular lymphocytic infiltrates in endometrial carcinoma. Cancer 91 1777-1784.

Yang X, Dong Y, Zhao J, Sun H, Deng Y, Fan J \& Yan Q 2007 Increased expression of human macrophage metalloelastase (MMP-12) is associated with the invasion of endometrial adenocarcinoma. Pathology, Research and Practice 203 499-505.

Yang HP, Garcia-Closas M, Lacey JV Jr, Brinton LA, Lissowska J, Peplonska B, Chanock S \& Gaudet MM 2009 Genetic variation in the androgen receptor gene and endometrial cancer risk. Cancer Epidemiology, Biomarkers and Prevention 18 585-589.
Yao C, Lin Y, Chua MS, Ye CS, Bi J, Li W, Zhu YF \& Wang SM 2007 Interleukin-8 modulates growth and invasiveness of estrogen receptornegative breast cancer cells. International Journal of Cancer 121 1949-1957.

Ye RD 2001 Regulation of nuclear factor $\mathrm{\kappa B}$ activation by G-protein-coupled receptors. Journal of Lenkocyte Biology 70 839-848.

Zamai L, Ponti C, Mirandola P, Gobbi G, Papa S, Galeotti L, Cocco L \& Vitale M 2007 NK cells and cancer. Journal of Immunology 178 4011-4016. Zhao D, Li XP, Gao M, Zhao C, Wang JL \& Wei LH 2006 Stromal cell-derived factor $1 \alpha$ stimulates human endometrial carcinoma cell growth through the activation of both extracellular signal-regulated kinase $1 / 2$ and Akt. Gynecologic Oncology 103 932-937.

Received in final form 15 April 2010

Accepted 20 April 2010

Made available online as an Accepted Preprint 20 April 2010 